\title{
Autophagy promotes mammalian survival by suppressing oxidative stress and p53
}

\author{
Yang Yang, ${ }_{1}^{1}$ Gizem Karsli-Uzunbas, ${ }^{1}$ Laura Poillet-Perez, ${ }^{1}$ Akshada Sawant, ${ }^{1}$ Zhixian Sherrie Hu, ${ }^{1}$ \\ Yuhan Zhao, ${ }^{1}$ Dirk Moore, ${ }^{1,2}$ Wenwei Hu, ${ }^{1,3}$ and Eileen White ${ }^{1,4}$ \\ ${ }^{1}$ Rutgers Cancer Institute of New Jersey, New Brunswick, New Jersey 08903, USA; ${ }^{2}$ Department of Biostatistics and Epidemiology, \\ Rutgers School of Public Health, Piscataway, New Jersey 08854, USA; ${ }^{3}$ Department of Radiation Oncology, Rutgers Cancer \\ Institute of New Jersey, New Brunswick, New Jersey 08903, USA; ${ }^{4}$ Department of Molecular Biology and Biochemistry, Rutgers \\ University, Piscataway, New Jersey 08854, USA
}

Autophagy captures intracellular components and delivers them to lysosomes for degradation and recycling. Conditional autophagy deficiency in adult mice causes liver damage, shortens life span to 3 mo due to neurodegeneration, and is lethal upon fasting. As autophagy deficiency causes $\mathrm{p} 53$ induction and cell death in neurons, we sought to test whether p53 mediates the lethal consequences of autophagy deficiency. Here, we conditionally deleted Trp53 (p53 hereafter) and/or the essential autophagy gene $\operatorname{Atg} 7$ throughout adult mice. Compared with $A \operatorname{tg} 7^{\Delta / \Delta}$ mice, the life span of $A \operatorname{tg} 7^{\Delta / \Delta} p 53^{\Delta / \Delta}$ mice was extended due to delayed neurodegeneration and resistance to death upon fasting. Atg7 also suppressed apoptosis induced by $\mathrm{p} 53$ activator Nutlin-3, suggesting that autophagy inhibited p53 activation. To test whether increased oxidative stress in $\operatorname{Atg} 7^{\Delta / \Delta}$ mice was responsible for p53 activation, Atg 7 was deleted in the presence or absence of the master regulator of antioxidant defense nuclear factor erythroid 2-related factor 2 (Nrf2). Nrf2 ${ }^{-/-} \mathrm{Atg} 7^{\Delta / \Delta}$ mice died rapidly due to small intestine damage, which was not rescued by $p 53$ codeletion. Thus, Atg7 limits p53 activation and p53-mediated neurodegeneration. In turn, NRF2 mitigates lethal intestine degeneration upon autophagy loss. These findings illustrate the tissue-specific roles for autophagy and functional dependencies on the p53 and NRF2 stress response mechanisms.

[Keywords: autophagy; ATG7; p53; DNA damage; apoptosis; NRF2; oxidative stress]

Supplemental material is available for this article.

Received December 2, 2019; revised version accepted February 20, 2020.

Autophagy is the process by which cells direct their own intracellular proteins, lipids, and organelles to the lysosomal compartment for degradation (Mizushima 2010). Generally, the autophagy pathway involves the formation of double membrane-bound vesicles called autophagosomes that capture cargo such as cytoplasmic proteins, organelles, and bacteria. Autophagosomes with cargo then fuse with lysosomes to form autolysosomes where the cargo is degraded (Kaur and Debnath 2015). The breakdown products are then released into the cytoplasm where they are recycled and specifically used as substrates for central carbon metabolism to sustain survival (Rabinowitz and White 2010; Guo et al. 2016). These functions of autophagy are controlled by the autophagy-related genes (Atg) and other proteins that enable the formation of autophagosomes and recognition and capture of cargos (Mizushima and Komatsu 2011).

Autophagy maintains organelle function, prevents the accumulation of toxic cellular waste products, and sustains cell metabolism and survival during starvation (Poil-

Corresponding author: epwhite@cinj.rutgers.edu Article published online ahead of print. Article and publication date are online at http://www.genesdev.org/cgi/doi/10.1101/gad.335570.119.
let-Perez and White 2019). Autophagy is required to prevent the accumulation of damaged mitochondria, which is particularly important in the liver, muscle, and brain. In fact, the buildup of damaged mitochondria can lead to oxidative stress and perturbation of metabolism (Rabinowitz and White 2010). Autophagy is also important for removal of damaged proteins, functioning incoordination with proteasome degradation for protein quality control (Pohl and Dikic 2019). Autophagy defects lead to endoplasmic reticulum (ER) stress and accumulation of chaperone proteins due to loss of the ability to remove the unfolded protein and properly remodel the proteome in response to stress (Mathew et al. 2009, 2014). Under stress conditions such as nutrient starvation, autophagy is dramatically induced and essential for stress adaptation (Mizushima et al. 2004). Cargo-selective autophagy is also important, for example, to recycle iron

(C) 2020 Yang et al. This article is distributed exclusively by Cold Spring Harbor Laboratory Press for the first six months after the full-issue publication date (see http://genesdev.cshlp.org/site/misc/terms.xhtml). After six months, it is available under a Creative Commons License (Attribution-NonCommercial 4.0 International), as described at http://creativecommons.org/licenses/by-nc/4.0/. 
from ferritin, which is critical for the iron homeostasis (Mancias et al. 2014).

Autophagy also has a critical role in mouse survival. Constitutively, Atg5- or Atg7-deficient mice are born developmentally normal but fail to survive the neonatal starvation period when the transplacental nutrient supply is interrupted but not yet restored by milk (Kuma et al. 2004; Komatsu et al. 2005). Force feeding only extends survival of autophagy-deficient newborn mice to neonatal starvation by $24 \mathrm{~h}$. In contrast to newborn mice, adult mice have a greater tolerance to the loss of autophagy. Conditional whole-body ablation of the essential autophagy gene $\operatorname{Atg} 7$ in adult mice shortens life span to 2 to 3 mo due to susceptibility to infection and neurodegeneration (Karsli-Uzunbas et al. 2014). Autophagy also suppresses liver, brain, and muscle damage and prevents depletion of white adipose tissue (WAT). While adult mice tolerate autophagy deficiency in the short term in the fed state, fasting is lethal within $16 \mathrm{~h}$ due to hypoglycemia (KarsliUzunbas et al. 2014). These findings demonstrate that autophagy is required to maintain systemic mammalian metabolism and survival by mitigating metabolic stress during nutrient deprivation (Karsli-Uzunbas et al. 2014). Moreover, there are remarkable tissue-specific dependencies on autophagy, with brain, liver, muscle, and WAT being particularly autophagy-dependent (Karsli-Uzunbas et al. 2014).

Many major stress responses are controlled by $\mathrm{p} 53$, and there is mounting evidence for a functional interaction between the p53 and the autophagy pathways. p53 is a transcription factor and tumor suppressor that responds to diverse types of stresses including DNA damage, oncogene activation, oxidative stress, and hypoxia (Fischer 2017). In response to stress, p53 can induce apoptosis, senescence, and cell cycle arrest, and alter cell metabolism by regulating multiple p53 target genes (Toledo and Wahl 2006). It is generally thought that the p53 stress response can provide either protection and facilitate adaptation and recovery (e.g., cell cycle arrest) in the case of mild stress, or can eliminate cells (e.g., apoptosis) with excessive damage in the setting of high levels of stress (Kruiswijk et al. 2015). p53 thereby controls the nature of the stress response and its outcome.

p53 can also regulate autophagy. Under nutrient deprivation, a low ATP/AMP ratio activates $5^{\prime}$ AMP-activated protein kinase (AMPK), which then induces p53. Induction of p53 activates the transcription of genes in the AMPK pathway including tuberous sclerosis complex 2 (TSC2) and AMPK itself, and leads to the inhibition of mTOR and activation of autophagy (Feng et al. 2007). Some p53 target genes like BCL2-associated X protein (BAX) and p53-up-regulated modulator of apoptosis (PUMA) can directly activate autophagy in MEF cells (Yee et al. 2009). p53 can also directly turn on the expression of essential autophagy genes or induce autophagy via transcriptional activation of damage-regulated autophagy modulator (DRAM-1) in human and mouse cell lines (Crighton et al. 2006; Mah et al. 2012; Kenzelmann Broz et al. 2013). Autophagy deficiency can cause p53 induction in mouse models of lung, pancreatic, and breast can- cer, and also in neurons, correlating with more apoptosis when p53 is intact, suggesting that autophagy may suppress p53 activation in some settings (Zhang et al. 2009; Yang et al. 2011; Guo et al. 2013; Huo et al. 2013; Rosenfeldt et al. 2013; Strohecker et al. 2013; Yang and Kimmelman 2014). As autophagy loss promotes p53 activation, and this p53 activation can be damaging, we sought to test the hypothesis that p53 was responsible for degenerative phenotypes induced by conditional autophagy loss in vivo.

To address how p53 and autophagy functionally interact in vivo and to determine the role that p53 plays in limiting the survival of mice without autophagy, we developed genetically engineered mouse models (GEMMs) to conditionally delete Atg7 and/or p53 systemically with tamoxifen (TAM). Whereas conditional, systemic $\operatorname{Atg} 7$ deletion $\left(\operatorname{Atg} 7^{\Delta / \Delta}\right)$ in adult mice limited their survival to 2-3 mo, codeletion of $p 53$ and $\operatorname{Atg} 7 \mid \operatorname{Atg} 7^{\Delta / \Delta}$ $p 53^{\Delta / \Delta}$ ) remarkably extended life span to up to $6 \mathrm{mo}$ and sustained survival during fasting. $\operatorname{Atg} 7^{\Delta / \Delta} p 53^{\Delta / \Delta}$ mice showed decreased tissue damage, apoptosis, and DNA damage in the liver and brain in comparison with $\operatorname{Atg} 7^{\Delta / \Delta}$ mice. Activation of p53 by Nutlin-3 was inhibited by autophagy, which protected liver and brain from p53 hyperactivation and apoptosis, suggesting that autophagy may be a resistance mechanism to p53 activators. NRF2, in turn, is a resistance mechanism to loss of autophagy as conditional deletion of both Nrf2 and Atg7 in adult mice was synthetically lethal. Mice deficient for both Atg7 and Nrf2 (Nrf2 ${ }^{-/-}$Atg $\left.7^{\Delta / \Delta}\right)$ succumbed to damage to the small intestine, which was independent of p53 function. Thus, Atg 7 protects against excessive $\mathrm{p} 53$ activation and damage in the liver and brain, whereas NRF- 2 protects the intestine from damage upon loss of $A t g 7$, demonstrating the functional interdependence and tissue specificity of stress response pathways.

\section{Results}

Loss of p53 delays neurodegeneration and prolongs survival of Atg7-deficient mice

To test whether p53 plays a role in limiting the survival in mice without autophagy, adult mice were engineered with or without floxed alleles of Atg7 (Kuma et al. 2004), p53 (Marino et al. 2000), and a transgene expressing a TAM-regulated Cre recombinase under the control of ubiquitin C promoter that is ubiquitously expressed in the whole body (Ubc-CreERT2) (Ruzankina et al. 2007). Injecting TAM activates Cre throughout these mice and the floxed alleles of $A \operatorname{tg} 7$ and/or p53 are deleted separately or together (Fig. 1A). Mice with systemic loss of Atg7 or p53 or both in all tissues are thereby generated and gene deletion was confirmed by qRT-PCR at 2, 5, and $8 \mathrm{wk}$ following the five consecutive days of TAM administration (Supplemental Fig. S1A). Loss of ATG7 protein expression was also associated with accumulation of an unprocessed form of microtubule-associated protein $1 \mathrm{~A} / 1 \mathrm{~B}$ light chain 3 (LC3-I), decrease in or absence of the processed (active) form of LC3 (LC3-II), and accumulation of the autophagy 
A

A
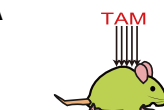

Ubc-CreERT2/+

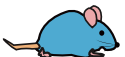

Ubc-CreERT2/; ; Atg7 $7^{\text {hox }}$

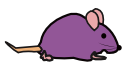

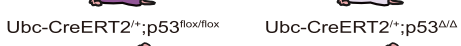

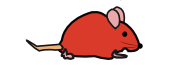

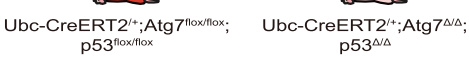

C

- Wild type $(n=27) \quad$ Log-rank Wilcoxon Log-rank Wilcoxon
- $\operatorname{Atg}^{\Delta \Delta}(\mathrm{n}=32)$

$+\mathrm{p} 53^{\Delta \Delta}(\mathrm{n}=50)$

$\left.\perp \operatorname{Atg}^{\Delta \Delta \Delta} 5^{\Delta{ }^{\Delta \Delta}}(\mathrm{n}=58)\right] \mathrm{n}$

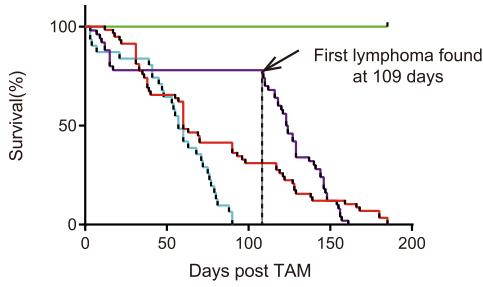

D

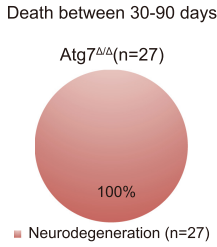

Death after 109 days

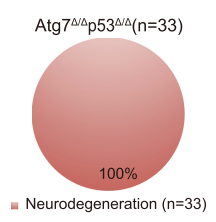
(first lymphoma)

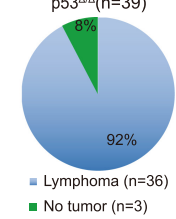

- No

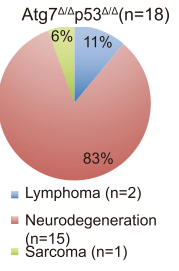

$\mathbf{F}$

- Wild Type $(n=27)$

$\left.\begin{array}{l}\perp p 53^{\Delta \Delta}(n=39) \\ +\operatorname{Atg}^{\Delta \Delta} \mathrm{p} 53^{\Delta \Delta}(n=18)\end{array}\right]{ }^{* * * *}$

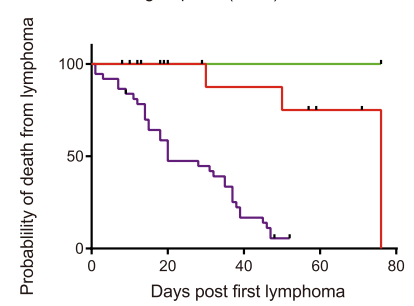

B

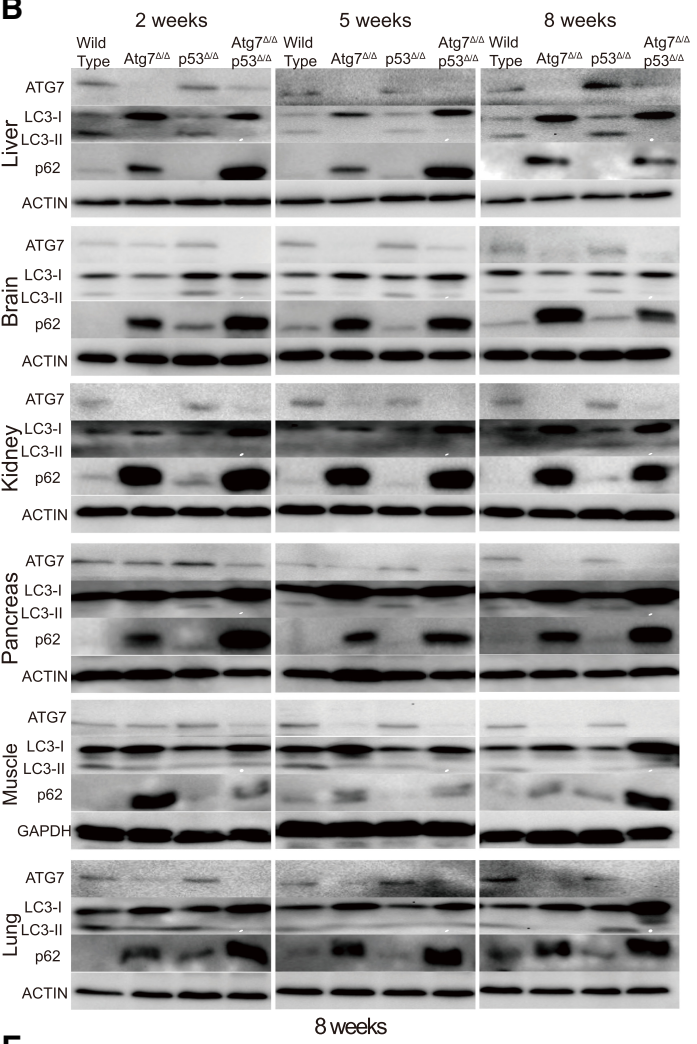

E liver muscle cerebrum cerebellum pancreas WAT lung

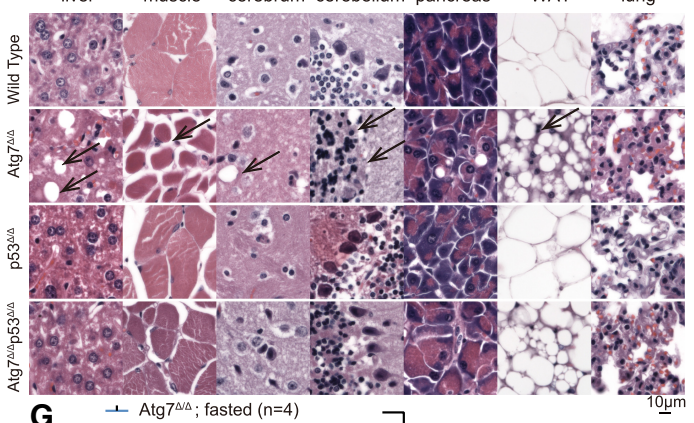

G $\quad \perp \operatorname{Atg}^{\Delta \Delta} ;$ fasted $(n=4)$

1 Wild Type; fasted $(n=3)$
1 . $03^{\Delta \Delta}$ : fasted $(n=3)$

$\perp \operatorname{Atg} 7^{N \Delta} \mathrm{p} 53^{N \Delta} ;$ fasted $(n=5)$

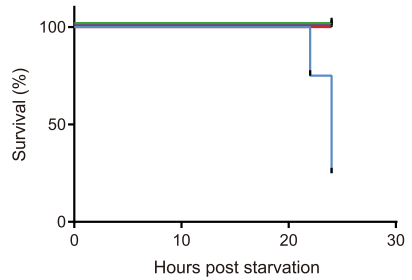

Figure 1. $\operatorname{Atg} 7^{\Delta / \Delta}, p 53^{\Delta / \Delta}$ mice have extended life span, delayed tissue damage and neurodegeneration compared with $A \operatorname{tg} 7^{\Delta / \Delta}$ mice. (A) Experimental design for generation of $A \operatorname{tg} 7^{\Delta / \Delta}$ mice, $p 53^{\Delta / \Delta}$ mice, and $A \operatorname{tg} 7^{\Delta / \Delta} p 53^{\Delta / \Delta}$ mice. Ubc-Cre ${ }^{E R T 2 /+}$, Ubc-Cre ${ }^{E R T 2 /+}$; Atg $7^{f l o x} / f l o x$ mice, Ubc-Cre ${ }^{E R T 2 /+} ; p 53^{\text {flox/flox }}$, Ubc-Cre ${ }^{E R T 2 /+} ; p 53^{\text {flox } / f l o x} ; A t g 7^{f l o x} /$ flox mice were treated with TAM at $8-10$ wk of age and analyzed at certain time points afterward. (B) Western blot for ATG7, p62, and LC3 at the indicated times of the indicated tissues from wild-type mice, $\operatorname{Atg} 7^{\Delta / \Delta}$ mice, $p 53^{\Delta / \Delta}$ mice, and $A \operatorname{tg} 7^{\Delta / \Delta} p 53^{\Delta / \Delta}$ mice. $\beta$-Actin was used as a loading control. (C) Kaplan-Meier survival curve of wild-type mice, $\operatorname{Atg} 7^{\Delta / \Delta}$ mice, $p 53^{\Delta / \Delta}$ mice, and $\operatorname{Atg} 7^{\Delta / \Delta} p 53^{\Delta / \Delta}$ mice. Dotted line indicates $109 \mathrm{~d}$, when the first lymphoma was identified in $p 53^{\Delta / \Delta}$ mice. (n.s,) Not significant; $\left(^{*}\right) P<0.05 ;\left(^{* *}\right) P<0.01 ;\left({ }^{* * * *}\right) P<0.0001$ (log-rank test and Gehan-Breslow-Wilcoxon test as indicated). (D) Percentage distribution for the cause of death of $\operatorname{Atg} 7^{\Delta / \Delta}, p 53^{\Delta / \Delta}$, and $A \operatorname{tg} 7^{\Delta / \Delta} p 53^{\Delta / \Delta}$ mice. The cause of death was analyzed at $30-90 \mathrm{~d}$ after TAM and 109-180 d after TAM. (E) Representative histology of liver, muscle, cerebrum, cerebellum, pancreas, white adipose tissue (WAT), and lung by hematoxylin and eosin stain (H\&E) from wild-type, $A \operatorname{tg} 7^{\Delta / \Delta}, p 53^{\Delta / \Delta}$, and $A \operatorname{tg} 7^{\Delta / \Delta} p 53^{\Delta / \Delta}$ mice at the 8 -wk time point. Black arrows indicate the damage site for these tissues. $(F)$ Kaplan-Meier survival curve of wild-type mice, $p 53^{\Delta / \Delta}$ mice, and $A \operatorname{tg} 7^{\Delta / \Delta} p 53^{\Delta / \Delta}$ mice that died after $109 \mathrm{~d}$. Black dots on the survival curve indicate the censoring times that mice died of no tumor development. $\left.{ }^{* * * *}\right) P<$ 0.0001 (log-rank test). (G) Kaplan-Meier survival curve of wild-type mice, $A \operatorname{tg} 7^{\Delta / \Delta}$ mice, $p 53^{\Delta / \Delta}$ mice, and $\operatorname{Atg} 7^{\Delta / \Delta} p 53^{\Delta / \Delta}$ mice during starvation at $10 \mathrm{~d}$ after TAM. $\left({ }^{*}\right) P<0.05$ (log-rank test). See also Supplemental Figure $\mathrm{S} 1$. 
substrate protein p62 in both $\operatorname{Atg} 7^{\Delta / \Delta}$ and $\operatorname{Atg} 7^{\Delta / \Delta} p 53^{\Delta / \Delta}$ mice, indicating blockage of autophagy function (Fig. 1B). $\operatorname{Atg} 7^{\Delta / \Delta}$ mice had a life span of $\sim 2-3 \mathrm{mo}$, primarily due to susceptibility to infection early, and to neurodegeneration later, which is consistent with our previous findings (Fig. 1C,D; Karsli-Uzunbas et al. 2014). Similar to constitutively deficient $p 53^{-/-}$mice, $p 53^{\Delta / \Delta}$ mice died from lymphoma, which limited life span to up to 6 mo (Fig. 1C,D; Donehower et al. 1995). In contrast to $A \operatorname{tg} 7^{\Delta / \Delta}$ mice, one-third of the $\operatorname{Atg} 7^{\Delta / \Delta} p 53^{\Delta / \Delta}$ mice lived $>3$ mo and up to 6 mo after TAM, while all of the $\operatorname{Atg} 7^{\Delta / \Delta}$ mice died before 3 mo after TAM (Fig. 1C,D). Although $\operatorname{Atg} 7^{\Delta / \Delta}$ $p 53^{\Delta / \Delta}$ lived longer than $A \operatorname{tg} 7^{\Delta / \Delta}$ mice, death was still predominantly from neurodegeneration (Fig. 1D). As loss of p53 did not alter survival to Atg7 deficiency early after deletion where death is due to susceptibility to infection (Karsli-Uzunbas et al. 2014), the role of p53 was specific to promoting death due to neurodegeneration (Fig. 1C, D). Therefore, p53 promotes neurodegeneration in mice deleted for Atg7.

\section{p53 deficiency reduces tissue damage in $\operatorname{Atg} 7^{\Delta / \Delta}$ mice}

Histological examination (H\&E) of tissues from wild-type, $\operatorname{Atg} 7^{\Delta / \Delta}, p 53^{\Delta / \Delta}$, and $\operatorname{Atg} 7^{\Delta / \Delta} p 53^{\Delta / \Delta}$ mice revealed no differences 2 wk after TAM (Supplemental Fig. S1B). At 5 wk after TAM, $\operatorname{Atg} 7^{\Delta / \Delta}$ mice began to show early evidence of loss of hepatocytes in the liver, pyramidal neurons in the cerebrum, Purkinje cells in the cerebellum, and depletion of lipid in WAT as reported previously (Karsli-Uzunbas et al. 2014), which was not observed in the $p 53^{\Delta / \Delta}$ or $A \operatorname{tg} 7^{\Delta / \Delta} p 53^{\Delta / \Delta}$ mice (Supplemental Fig. S1C). Two months after TAM, $\operatorname{Atg} 7^{\Delta / \Delta}$ mice showed severe loss of hepatocytes, pyramidal neurons, Purkinje cells, and WAT, as well as muscle wasting, whereas the kidneys and lungs were not affected (Fig. 1E; Supplemental Fig. S1D; Karsli-Uzunbas et al. 2014). In contrast, these tissue damage phenotypes resulting from Atg7 deficiency were not observed in wild-type, $p 53^{\Delta / \Delta}$, and $\operatorname{Atg} 7^{\Delta / \Delta} p 53^{\Delta / \Delta}$ mice (Fig. 1E; Supplemental Fig. S1D). These results suggest that tissue damage caused by autophagy deficiency is induced by p53. $\operatorname{Atg} 7^{\Delta / \Delta} p 53^{\Delta / \Delta}$ mice did display the same phenotype as the $\operatorname{Atg} 7^{\Delta / \Delta}$ mice at 16 wk after deletion (Supplemental Fig. S1E), indicating that loss of p53 delays but does not prevent lethal neurodegeneration caused by autophagy deficiency.

\section{ATG7 is required for tumorigenesis driven by p53 deletion}

Constitutive p53 deficiency leads to the development of lethal thymic lymphomas, which limits life span to $\sim 6$ mo (Donehower et al. 1995). Here, conditional p53 deficiency in adult mice $\left(p 53^{\Delta / \Delta}\right)$ produced the same phenotype as 36 out of 39 mice died of thymic lymphoma between 3 and 6 mo after deletion (Fig. 1C,D). $\operatorname{Atg} 7^{\Delta / \Delta} p 53^{\Delta / \Delta}$ mice showed similar life span limitation as the $p 53^{\Delta / \Delta}$ mice; however, the vast majority of the mice died from neurodegeneration without tumor development. Fifteen out of $18 \operatorname{Atg} 7^{\Delta / \Delta} p 53^{\Delta / \Delta}$ mice died of neurodegeneration after the first lymphoma was identified in $p 53^{\Delta / \Delta}$ mice at $109 \mathrm{~d}$ after TAM (Fig. 1C,D). Of the three $\operatorname{Atg} 7^{\Delta / \Delta} p 53^{\Delta / \Delta}$ mice that died from cancer, two died from thymic lymphomas and one died from a sarcoma, in which all of these tumors were deleted for Atg7 and p53 (Fig. 1D; Supplemental Fig. S1F). Analysis of the Kaplan-Meier survival curve for $p 53^{\Delta / \Delta}$ and $\operatorname{Atg} 7^{\Delta / \Delta} p 53^{\Delta / \Delta}$ mice that died after $109 \mathrm{~d}$ revealed that the death probability from lymphoma in $\operatorname{Atg} 7^{\Delta / \Delta} p 53^{\Delta / \Delta}$ mice is much lower compared with $p 53^{\Delta / \Delta}$ mice $(P$-value $<0.0001$, Log-rank test) (Fig. 1F). Thus, Atg7 promotes development of lethal thymic lymphomas driven by deletion of p53, consistent with the tumor-promoting role for autophagy reported in other settings (Poillet-Perez and White 2019).

p53 deficiency prevents fasting lethality in $\operatorname{Atg} 7^{\Delta / \Delta}$ mice While $\operatorname{Atg} 7^{\Delta / \Delta}$ mice survive in the short term, in contrast to wild-type mice, fasting is lethal within $16 \mathrm{~h}$ due to hypoglycemia (Karsli-Uzunbas et al. 2014). Since p53 deficiency extended the life span and attenuated tissue damage in $\operatorname{Atg} 7^{\Delta / \Delta}$ mice, we sought to test whether p53 contributes to the death of $A \operatorname{tg} 7^{\Delta / \Delta}$ mice during fasting. In contrast to $\operatorname{Atg} 7^{\Delta / \Delta}$ mice where fasting was lethal, none of the $\operatorname{Atg} 7^{\Delta / \Delta} p 53^{\Delta / \Delta}$ mice died upon fasting, suggesting that p53 was responsible for fasting-induced death of Atg7-deficient mice (Fig. 1F).

\section{ATG7 is required to protect the liver and brain from p53-} mediated damage

Autophagy deficiency causes p53 induction in neurons and in some cancer models and promotes cell death. Therefore, we tested whether p53 induction occurred in the whole body after Atg7 deletion. Immunohistochemistry (IHC) for p53 protein revealed that p53 accumulation was detectable at $2 \mathrm{wk}$ after TAM administration, and was maintained at 5 and 8 wk after TAM in the livers and brains of $\operatorname{Atg} 7^{\Delta / \Delta}$ mice, while p53 activation was not apparent in wild-type, $p 53^{\Delta / \Delta}$, and $\operatorname{Atg} 7^{\Delta / \Delta} p 53^{\Delta / \Delta}$ mice (Fig. 2A; Supplemental Fig. S2A,B). qRT-PCR for the p53 target genes cyclin-dependent kinase inhibitor $1 \mathrm{~A}$ $(C d k n 1 a$, or p21), BCL2-associated X (Bax), and BCL2binding component $3(B b c 3$, or Puma) showed increased $C d k n 1 a, B a x$, and $B b c 3$ expression in $A \operatorname{tg} 7^{\Delta / \Delta}$ mice at 2, 5 , and 8 wk after TAM in the liver and brain compared with wild-type, $p 53^{\Delta / \Delta}$, and $A \operatorname{tg} 7^{\Delta / \Delta} p 53^{\Delta / \Delta}$ mice (Fig. 2B, C). These data suggest that loss of $A \operatorname{tg} 7$ promotes activation of $\mathrm{p} 53$.

Whole-body ATG7 deficiency leads to DNA damage and apoptosis in the liver and cerebrum (Karsli-Uzunbas et al. 2014) and p53 is known to be activated by different stress signals including DNA damage and oxidative stress, and triggers cell cycle arrest and apoptosis (Fischer 2017). Therefore, we hypothesized that p53 induction in $\operatorname{Atg} 7^{\Delta / \Delta}$ mice may promote apoptosis. IHC for the DNA damage response activation marker $\gamma-\mathrm{H} 2 \mathrm{AX}$ revealed accumulation of $\gamma-\mathrm{H} 2 \mathrm{AX}$ in $\operatorname{Atg} 7^{\Delta / \Delta}$ liver hepatocytes, neurons, and nonneuronal cells in cerebrum starting at $2 \mathrm{wk}$ that 

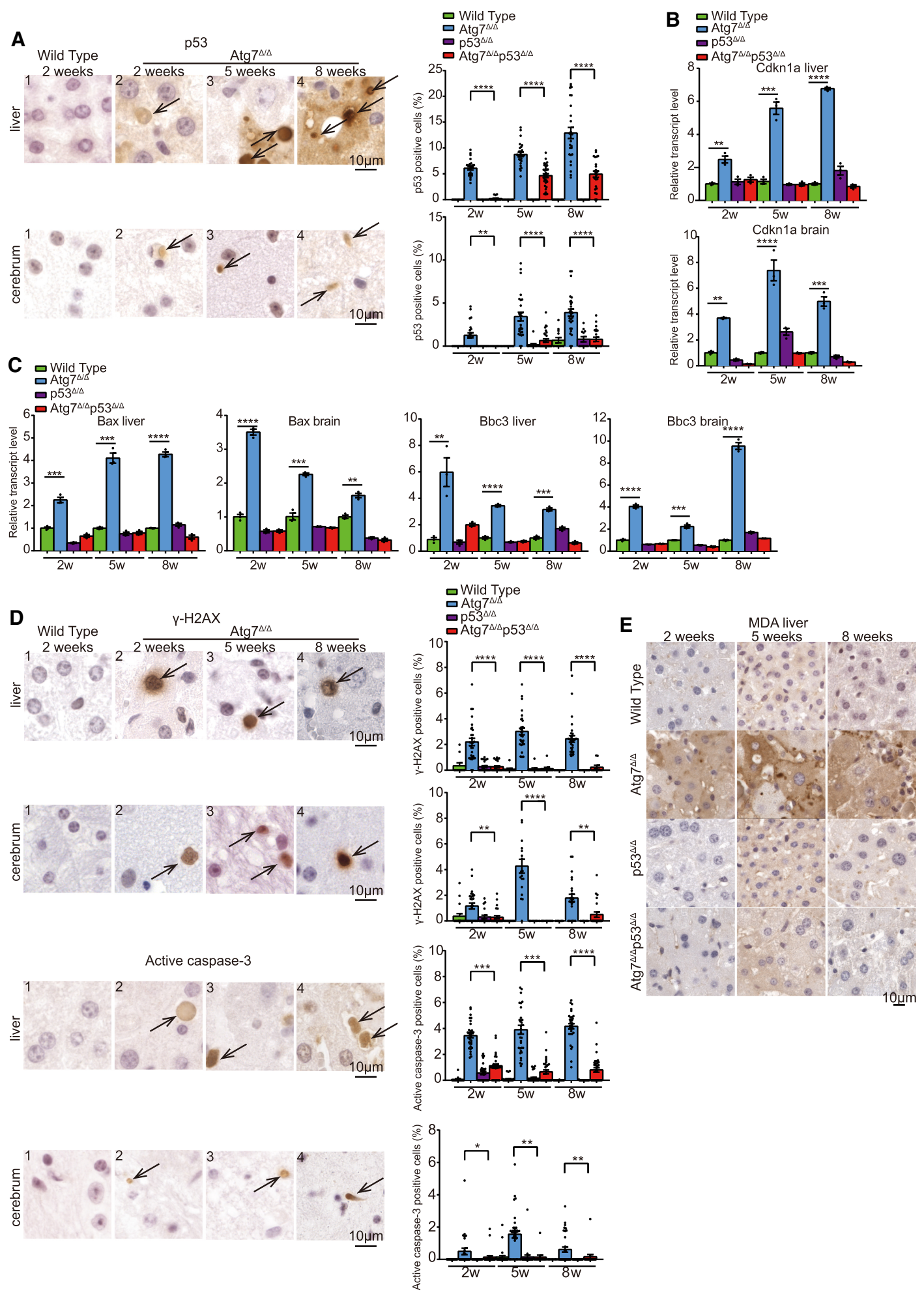

Figure 2. Autophagy is required to protect liver and brain from p53 accumulation, DNA damage response activation, and apoptosis. (A) Representative liver and cerebrum IHC staining of p53 and quantification at the indicated times from wild-type and $A t g 7^{\Delta / \Delta}$ mice. Black arrows indicate p53-positive cells. (2w) 2-wk time point; (5w) 5-wk time point; (8w) 8-wk time point. $(B, C)$ Quantitative real-time PCR of $C d k n 1 a, B a x$, and $B b c 3$ for liver and brain tissues from wild-type, $A \operatorname{tg} 7^{\Delta / \Delta}, p 53^{\Delta / \Delta}$, and $A \operatorname{tg} 7^{\Delta / \Delta} p 53^{\Delta / \Delta}$ mice at the indicated times. $\left(^{* *}\right) P<$ $\left.\left.0.01 ;{ }^{* * *}\right) P<0.001 ;{ }^{* * * *}\right) P<0.0001$ (unpaired $t$-test). $(D)$ Representative liver and cerebrum IHC staining for $\gamma$-H2AX and active caspase-3 with quantification at the indicated times from wild-type and $A \operatorname{tg} 7^{\Delta / \Delta}$ mice. Black arrows indicate $\gamma$-H2AX or active caspase-3-positive cells. $(2 \mathrm{w}) 2 \mathrm{wk} ;(5 \mathrm{w}) 5 \mathrm{wk} ;(8 \mathrm{w}) 8 \mathrm{wk} .\left(^{*}\right) P<0.05 ;\left(^{* *}\right) P<0.01 ;(* *) P<0.001\left(^{* * * *}\right) P<0.0001$ (unpaired $t$-test). (E) Representative liver IHC staining for MDA at the indicated times from wild-type, $\operatorname{Atg} 7^{\Delta / \Delta}, p 53^{\Delta / \Delta}$, and $\operatorname{Atg} 7^{\Delta / \Delta} p 53^{\Delta / \Delta}$ mice. See also Supplemental Figure S2. 
was apparent through 8 wk after TAM (Fig. 2D; Supplemental Fig. S2C,D). In contrast, $\gamma$-H2AX accumulation was not detected in wild-type, $p 53^{\Delta / \Delta}$, and $\operatorname{Atg} 7^{\Delta / \Delta}$ $p 53^{\Delta / \Delta}$ mice (Supplemental Fig. S2C,D). As a likely consequence of p53 activation in $\operatorname{Atg} 7^{\Delta / \Delta}$ mice, they also showed more apoptosis marked by increased active caspase-3 in liver hepatocytes, neurons, and nonneuronal cells in cerebrum in comparison with $\operatorname{Atg} 7^{\Delta / \Delta} p 53^{\Delta / \Delta}$ mice (Fig. 2D; Supplemental Fig. S2E,F). These data indicated that p53 induction caused apoptosis in $\operatorname{Atg} 7^{\Delta / \Delta}$ mice. $\operatorname{Atg} 7^{\Delta / \Delta}$ mice also displayed increased malondialdehyde (MDA) in the liver by IHC compared with wild-type, $p 53^{\Delta / \Delta}$, and $\operatorname{Atg} 7^{\Delta / \Delta} p 53^{\Delta / \Delta}$ mice, indicating that p53 induction was associated with increased oxidative stress in $\operatorname{Atg} 7^{\Delta / \Delta}$ mice (Fig. 2E). As the phenotype of the $\operatorname{Atg} 7^{\Delta / \Delta} p 53^{\Delta / \Delta}$ mice was similar to the $\operatorname{Atg} 7^{\Delta / \Delta}$ mice, just delayed, this suggests that other responses similar to p53 act later when p53 is absent. It is intriguing to speculate that other p53 family members, such as p63 and p73, may be responsible for the neurodegeneration in the $\operatorname{Atg} 7^{\Delta / \Delta} p 53^{\Delta / \Delta}$ mice.

\section{ATG7 limits p53 activation by Nutlin-3a}

Regulation of p53 activity relies on the essential p53 antagonist MDM2, which is a direct transcriptional target of p53 and is up-regulated when p53 is activated by phosphorylation at specific serine and threonine residues (Bode and Dong 2004). MDM2 binds to p53, and the ubiquitin E3 ligase of MDM2 ubiquitinylates p53, which decreases its stability by targeting it to the proteasome for degradation (Honda et al. 1997; Kubbutat et al. 1997; Matsumine et al. 1997). Under stress conditions, p53 is phosphorylated at its transactivation domain (Ser15, Ser20, and Thr18), which disrupts its binding of MDM2, and is thereby stabilized and activated (Craig et al. 1999). In this way, p53 and MDM2 form a negative feedback loop resulting from $\mathrm{p} 53$ dependent induction of MDM2 and MDM2-dependent suppression of p53 activity, which helps the cell to deal with stress without hyperactivation of p53 (Montes de Oca Luna et al. 1995; Dotto 2009; Marine and Lozano 2010). Nutlin-3 works as an MDM2 antagonist and upregulates the cellular p53 level by competing for the p53-binding site on MDM2, and is being assessed clinically to promote p53 activation for cancer therapy (Vassilev et al. 2004; Drost et al. 2015; Yee-Lin et al. 2018; Forte et al. 2019). Since Atg7 limits p53 accumulation and activation, we sought to test whether Atg7 also limited the ability of Nutlin-3 to activate p53 (Khoury and Domling 2012) as a potential resistance mechanism in normal tissues.

Following deletion of Atg7 and/or p53, mice were treated with either vehicle or Nutlin-3 (200 mg/ $\mathrm{kg}$ ) once per day for 1 wk (Fig. 3A). Deletion of Atg7 and p53 was confirmed by qRT-PCR (Supplemental Fig. S3A). Western blot for loss of ATG7 protein, accumulation of LC3-I and loss of LC3-II, and accumulation of p62 in the livers and brains from $\operatorname{Atg} 7^{\Delta / \Delta}$ and $\operatorname{Atg} 7^{\Delta / \Delta} p 53^{\Delta / \Delta}$ mice indicated blockage of autophagy (Fig. 3B). As described previously, liver damage and neuron loss in $A \operatorname{tg} 7^{\Delta / \Delta}$ mice were con- firmed by H\&E, which was not affected by Nutlin-3 (Supplemental Fig. S3B). IHC of the livers and brains from $\operatorname{Atg} 7^{\Delta / \Delta}$ mice revealed increased p53 compared with wild-type mice, which was further increased in Nutlin3-treated $\operatorname{Atg} 7^{\Delta / \Delta}$ mice, suggesting that Nutlin-3 induced p53 in the absence but not in the presence of autophagy. As expected, Nutlin-3 did not affect p53 levels in p53 ${ }^{\Delta / \Delta}$ mice and $A \operatorname{tg} 7^{\Delta / \Delta} p 53^{\Delta / \Delta}$ mice (Fig. 3C; Supplemental Fig. S3C). qRT-PCR for the p53 target genes Cdkn1a, Bax, and $B b c 3$ showed increased Cdkn1a, Bax, and Bbc3 expression in untreated $\operatorname{Atg} 7^{\Delta / \Delta}$ mice, which was further increased in Nutlin-3-treated $A \operatorname{tg} 7^{\Delta / \Delta}$ mice in the liver and brain compared with vehicle or Nutlin-3-treated wildtype mice (Fig. 3D). This suggested that p53 was activated by Nutlin-3 only in the absence of Atg7 in normal tissues such as liver and brain. IHC of liver and brain revealed increased $\gamma$-H2AX and active caspase-3 in $\operatorname{Atg} 7^{\Delta / \Delta}$ mice compared with wild-type mice, and activation of $\mathrm{p} 53$ by Nutlin-3 greatly increased $\gamma-\mathrm{H} 2 \mathrm{AX}$ and active caspase-3 levels. Induction of $\gamma-\mathrm{H} 2 \mathrm{AX}$ and active caspase- 3 were not observed in $p 53^{\Delta / \Delta}$ and $A \operatorname{tg} 7^{\Delta / \Delta} p 53^{\Delta / \Delta}$ mice, suggesting that loss of autophagy induced apoptosis through p53 activation (Fig. 3E; Supplemental Fig. S3D,E). Therefore, autophagy is essential to protect tissues from apoptosis by limiting p53 activation.

Since p53 can induce a series of essential autophagy genes including Atg7 in MEF cells (Kenzelmann Broz et al. 2013), we hypothesized that up-regulation of p53 by Nutlin-3 can turn on essential autophagy genes and protect tissues from damage caused by p53 induction in wild-type mice. Real-time PCR on a series of autophagy essential genes indicated no significant difference in the autophagy gene mRNA levels, suggesting that the autophagy transcription program is not detectably induced by p53 at the times the tissues were collected (Supplemental Fig. S4).

\section{Atg7 deficiency is synthetically lethal in the absence} of Nrf2

Autophagy can reduce reactive oxygen species (ROS) by removing damaged mitochondria and unfolded protein, and autophagy deficiency leads to increased ROS and accumulation of unfolded protein (Manjithaya et al. 2010; Mizushima 2010). Since we found induction of oxidative stress markers in $\operatorname{Atg} 7^{\Delta / \Delta}$ mice (Fig. 2E), we investigated whether the increased oxidative stress was responsible for tissue damage caused by p53 activation. NRF2 is the master regulator of the antioxidant defense and is ubiquitinated by an E3 ubiquitin ligase Kelch-like ECH-associated protein 1 (KEAP1) and degraded by the proteosome pathway under normal conditions (Kensler et al. 2007). With increased ROS, NRF2 is released from KEAP1 and triggers expression of a series of antioxidant genes, and NRF2 is induced by autophagy deficiency (Komatsu et al. 2010; Lau et al. 2010; Levonen et al. 2014). To examine the role of antioxidant defense in mice lacking autophagy, mice with constitutive deficiency in Nrf2 (Chan et al. 1996) were crossed with $U b c-C r e^{E R T 2 /+}$; Atg $7^{\text {flox } / f l o x}$ mice to generate $\mathrm{Nrf2}^{-/-} ; \mathrm{Ubc}-\mathrm{Cr} \mathrm{E}^{\mathrm{ERT2/+}} ; \mathrm{Atg} 7^{\text {flox/flox }}$ mice (Fig. 
A
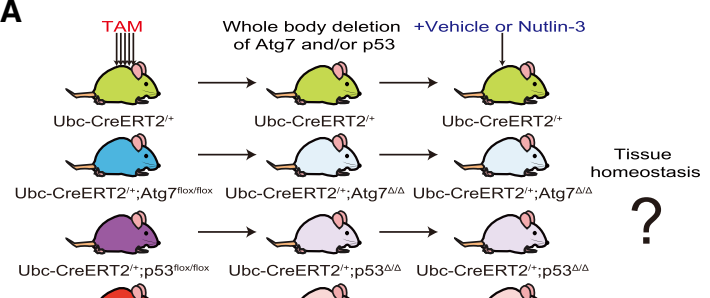

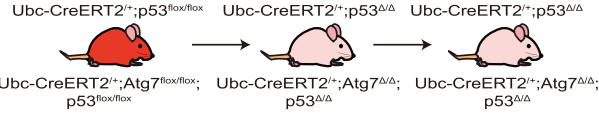

c
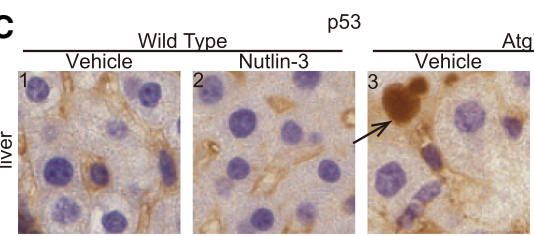

$\operatorname{Atg} 7^{\Delta \Delta}$
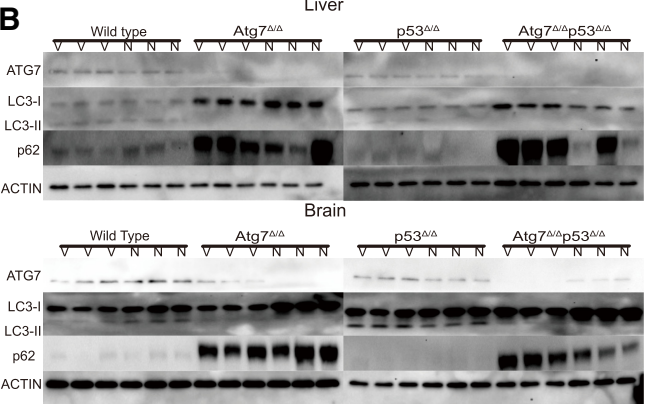

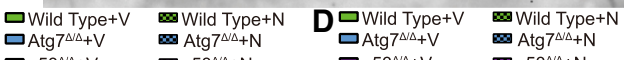

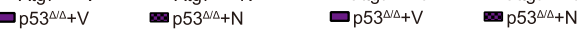

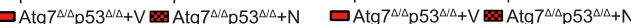

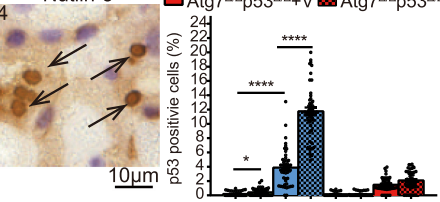

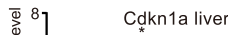
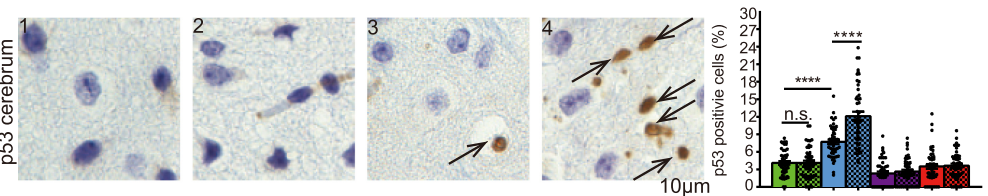
$\begin{array}{ll}\text { 口Wild Type }+V & \text { aild Type }+N \\ \text { 口Atg7 } 7^{\Delta \Delta+V} & \text { Atg } 7^{\Delta \Delta+N}\end{array}$

口 $53^{\Delta \Delta}+\mathrm{V}$

Wild Type
Atg7
a $53^{\Delta \Delta \Delta+N}+N$

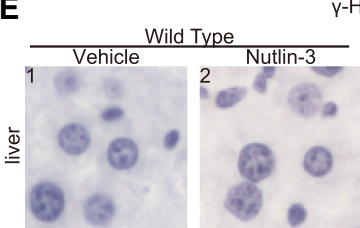

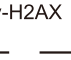
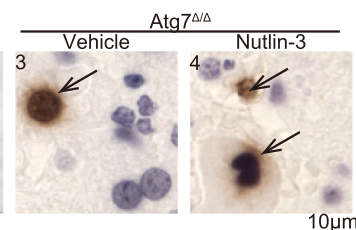

$A \operatorname{tg} 7^{\Delta \Delta} p 53^{\Delta \Delta}+V$ 圆Atg $7^{\Delta \Delta} p 53^{\Delta \Delta+N}$
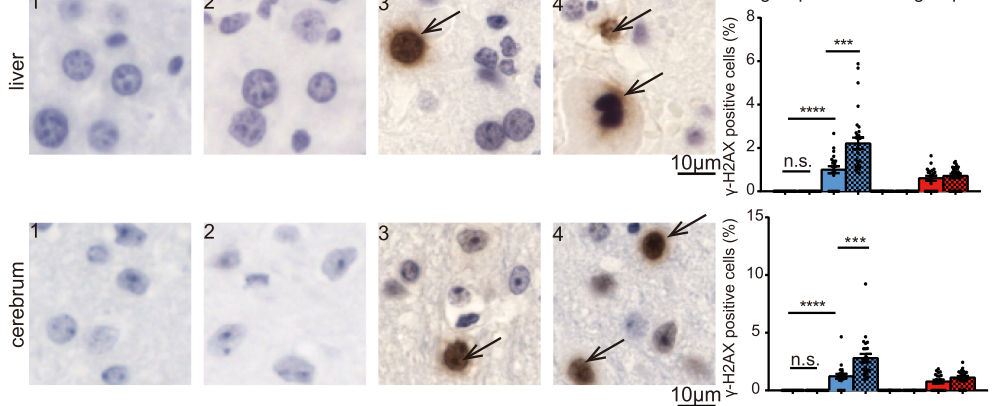

Active caspase-3
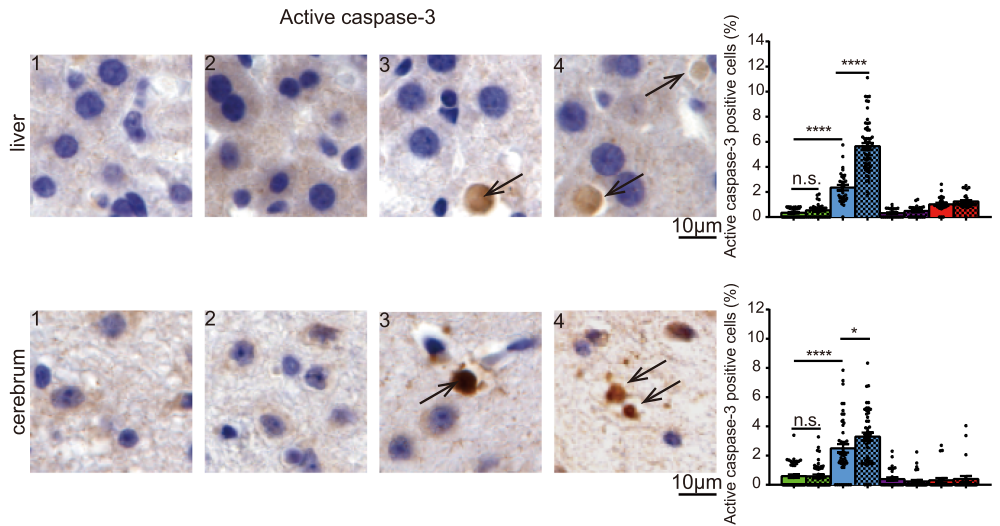
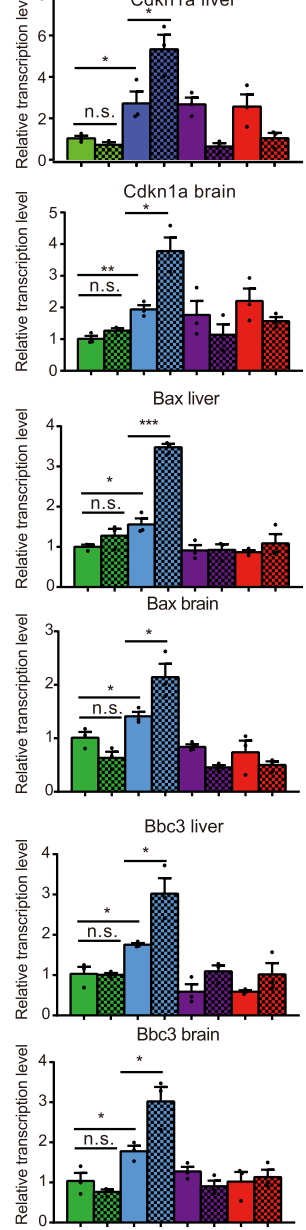

Figure 3. Activation of p53 by MDM2 antagonist Nutlin-3a in $\operatorname{Atg} 7^{\Delta / \Delta}$ mice leads to further increased DNA damage response and apoptosis in the liver and brain. (A) Experimental design for generation of $A \operatorname{tg} 7^{\Delta / \Delta}, p 53^{\Delta / \Delta}$, and $\operatorname{Atg} 7^{\Delta / \Delta} p 53^{\Delta / \Delta}$ mice and Nutlin-3 administration. Nutlin-3 was administered to mice by oral gavage $2 \mathrm{wk}$ after TAM administration at a dosage of $200 \mathrm{mg} / \mathrm{kg}$ for $1 \mathrm{wk}$. (B) Western blot for ATG7, p62, and LC3 for liver and brain tissues from wild-type, $\operatorname{Atg} 7^{\Delta / \Delta}, p 53^{\Delta / \Delta}$, and $A \operatorname{tg} 7^{\Delta / \Delta} p 53^{\Delta / \Delta}$ mice treated with vehicle or Nutlin3. $\beta$-Actin was used as a loading control. (V) Treated with vehicle; (N) treated with Nutlin-3. (C) Representative liver and cerebrum IHC staining for p53 and quantification from wild-type and $\operatorname{Atg} 7^{\Delta / \Delta}$ mice treated with vehicle or Nutlin-3. Black arrows indicate p53-positive cells. (V) Vehicle; (N) Nutlin-3. $\left(^{*}\right) P<0.05 ;\left({ }^{* * *}\right) P<0.0001$; (n.s.) not significant (unpaired $t$-test). $(D)$ Quantitative real-time PCR of $C d k n 1 a, B a x$, and $B b c 3$ for liver and brain tissues from wild-type, $A \operatorname{tg} 7^{\Delta / \Delta}, p 53^{\Delta / \Delta}$, and $A \operatorname{tg} 7^{\Delta / \Delta} p 53^{\Delta / \Delta}$ mice treated with vehicle or Nutlin-3. (V) Vehicle; (N) Nutlin-3. $\left({ }^{*}\right) P<0.05 ;\left(^{* *}\right) P<0.01 ;\left(^{* * *}\right) P<0.001$; (n.s.) not significant (unpaired $t$-test). $(E)$ Representative liver and cerebrum IHC staining for $\gamma-\mathrm{H} 2 \mathrm{AX}$ and active caspase-3 with quantification from wild-type and $A \operatorname{tg} 7^{\Delta / \Delta}$ mice treated with vehicle or Nutlin-3. Black arrows indicate $\gamma$-H2AX or active caspase-3-positive cells. (V) Vehicle; (N) Nutlin-3. $\left(^{*}\right) P<0.05 ;\left(^{* * *}\right) P<0.001$; $\left.{ }^{(* * * *}\right) P<0.0001$; (n.s.) not significant (unpaired $t$-test). 
A

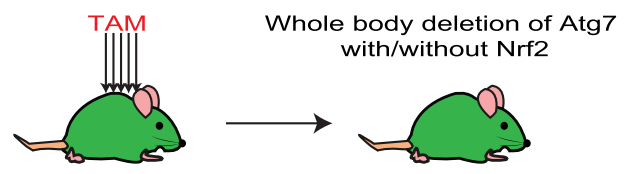

Ubc-CreERT2 $2^{\prime+}$
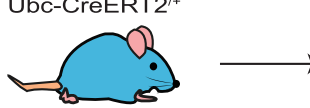

Ubc-CreERT2/+

Ubc-CreERT2 $2^{\prime+} ; A \operatorname{Atg} 7^{\text {flox/flox }} \quad$ Ubc-CreERT2 ${ }^{/+} ;$Atg $^{\Delta / \Delta}$

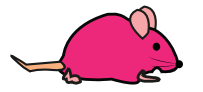

Nrf2-"-; Ubc-CreERT2/+

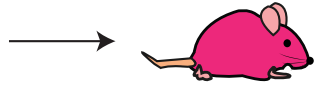

$\mathrm{Nrf2}^{-1-} ;$ Ubc-CreERT2/
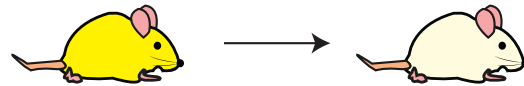

$\mathrm{Nrf2}^{--/} ;$Ubc-CreERT2 ${ }^{/+} ; \mathrm{Atg}^{\text {flox/flox }} \mathrm{Nrf2}^{-1-} ;$ Ubc-CreERT2 $2^{\prime+} ; \mathrm{Atg}^{\Delta / \Delta}$
B

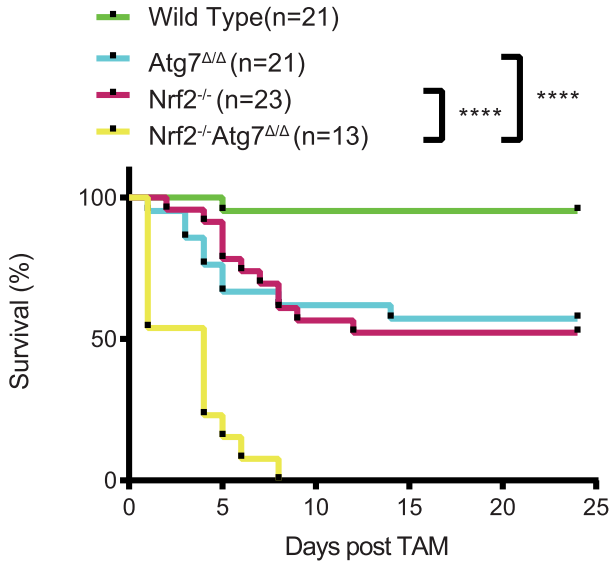

C

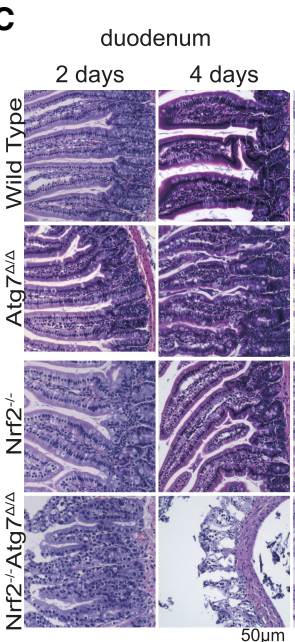

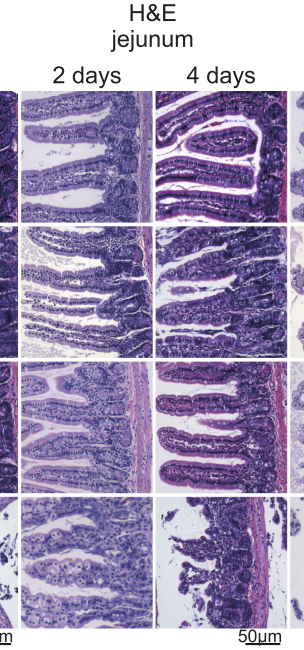

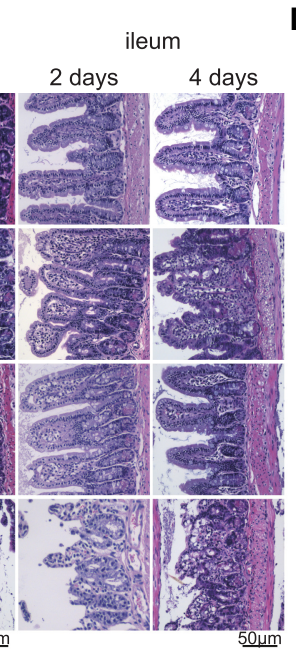

D

Dodipy C11 duodenum jejunum 2 days 4 days 2 days 4 days 2 days 4 days

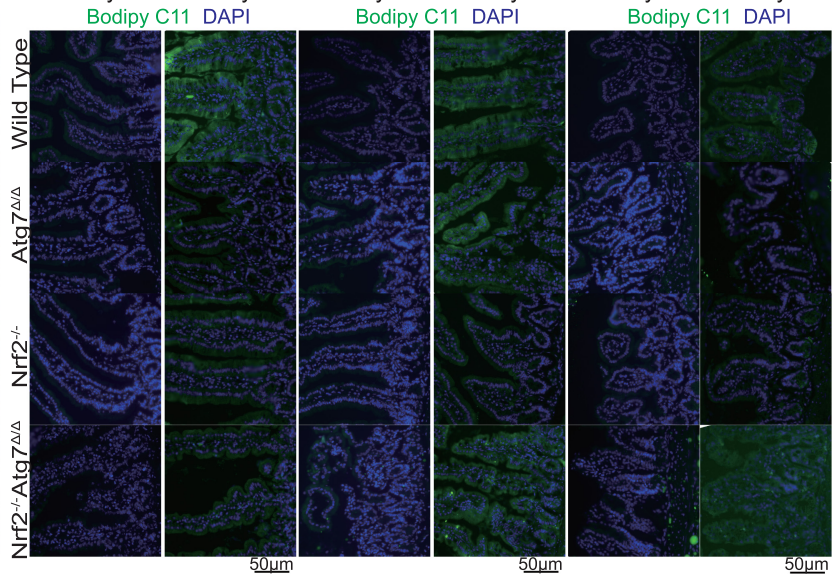

F OLFM4

$\mathbf{F}$

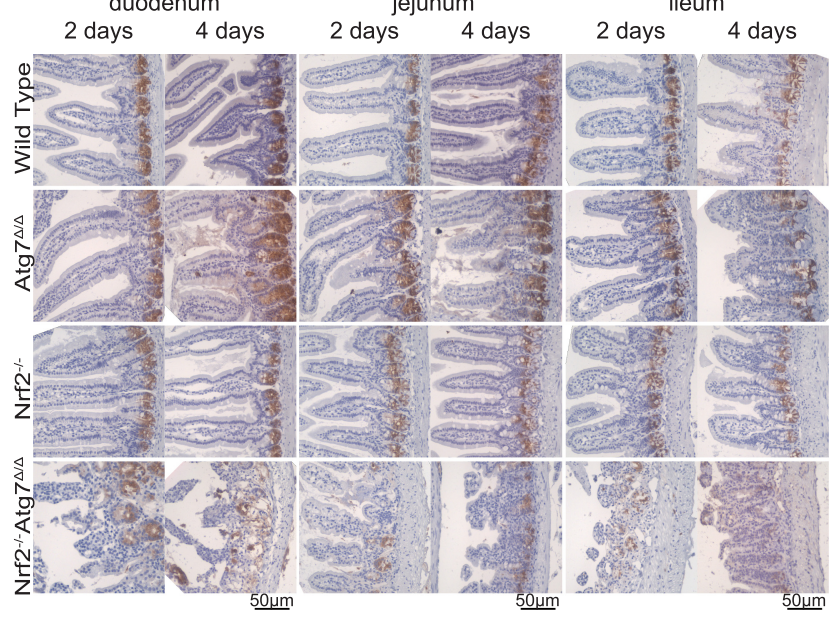

Figure 4. Atg7 deficiency is synthetically lethal in the absence of Nrf2. (A) Experimental design for generation of Atg $7^{\Delta / \Delta}$ mice, Nrf2 ${ }^{-/-}$ mice, and $N r f 2^{-/-} A \operatorname{tg} 7^{\Delta / \Delta}$ mice. (B) Kaplan-Meier survival curve of wild-type, $A \operatorname{tg} 7^{\Delta / \Delta}, N r f 2^{-/-}$, and $N r f 2^{-/-} A \operatorname{tg} 7^{\Delta / \Delta}$ mice. $\left(^{* * * *}\right) P<0.0001$ (log-rank [Mantel-Cox] test). (C) Representative histology of duodenum, jejunum, and ileum by H\&E at the indicated times from wildtype, $\operatorname{Atg} 7^{\Delta / \Delta}, N r f 2^{-/-}$, and $N r f 2^{-/-} A \operatorname{tg} 7^{\Delta / \Delta}$ mice. $(D)$ Representative Bodipy C11 stain of duodenum, jejunum, and ileum at the indicated times from wild-type, $\operatorname{Atg} 7^{\Delta / \Delta}, N r f 2^{-/-}$, and $N r f 2^{-/} A \operatorname{tg} 7^{\Delta / \Delta}$ mice. (E) Representative Alcian blue stain of duodenum, jejunum, and ileum at the indicated times from wild-type, $\operatorname{Atg} 7^{\Delta / \Delta}, \mathrm{Nrf2^{-/- }}$, and $N r f 2^{-/-} A \operatorname{tg} 7^{\Delta / \Delta}$ mice. $(F)$ Representative duodenum, jejunum, and ileum IHC stain of OLFM4 at the indicated times from wild-type, $\operatorname{Atg} 7^{\Delta / \Delta}, N r f 2^{-/-}$, and $N r f 2^{-/-} \operatorname{Atg}^{\Delta / \Delta}$ mice. 
4A). TAM administration was then used to delete $A \operatorname{tg} 7$ in the presence and absence of Nrf2.

In contrast to $A \operatorname{tg} 7^{\Delta / \Delta}$ and $N r 2^{-/-}$mice, most of which survive, $N r f 2^{-/} A \operatorname{tg} 7^{\Delta / \Delta}$ mice had a life span of $<7 \mathrm{~d}$ (Fig. 4B). Histological examination of tissues by $\mathrm{H} \& \mathrm{E}$ surprisingly showed no damage to the liver, brain, pancreas, lungs, and kidneys in $N r f 2^{-1-} A \operatorname{tg} 7^{\Delta / \Delta}$ mice (Supplemental Fig. S5A). The only tissue with significant damage was the intestine (duodenum, jejunum, and ileum), which may be the cause of increased muscle wasting and loss of WAT (Fig. 4C; Supplemental Fig. S5B). Bodipy C11 staining of the whole small intestine was significantly increased in $N r f 2^{-/-} \operatorname{Atg} 7^{\Delta / \Delta}$ intestine, indicating increased lipid peroxidation that results from ROS (Fig. 4D). IHC for active caspase-3 displayed increased staining in $N r f 2^{-/-} A \operatorname{tg} 7^{\Delta / \Delta}$ intestine in both the crypt and villus, indicating increased apoptosis (Supplemental Fig. S5C-E). Thus, conditional deletion of the essential autophagy gene $\operatorname{Atg} 7$ in adult mice is synthetically lethal in the absence of Nrf2 due to damage to the intestine.

We then investigated which cell type in the intestine was most affected by deficiency in Atg7 in the absence of Nrf2. Alcian blue staining of paraffin sections from intestine tissues was significantly decreased in the $N r 2^{-/-} \operatorname{Atg} 7^{\Delta / \Delta}$ mouse intestine, suggesting loss of goblet cells (Fig. 4E). IHC for the stem cell marker OLFM4 revealed loss of OLFM4 staining in $N r f 2^{-/-} \operatorname{Atg} 7^{\Delta / \Delta}$ but not in wild-type, $\operatorname{Atg} 7^{\Delta / \Delta}$, and $N r f 2^{-/-}$mouse intestine, suggesting loss of stem cells (Fig. 4F). IHC for the Paneth cell marker Lysozyme revealed diffuse staining in the $N r f 2^{-/-} \operatorname{Atg} 7^{\Delta / \Delta}$ mouse intestines in comparison with wild-type, $\operatorname{Atg} 7^{\Delta / \Delta}$, and $N r f 2^{-/-}$intestines, which suggests that Paneth cell function is abnormal (Supplemental Fig. S5F; Cadwell et al. 2008). We then investigated whether this deleterious phenotype in the intestine was induced by $\mathrm{p} 53$ activation. $p 53^{\text {flox/flox }}$ mice were crossed with $\mathrm{Nrf2}^{-/-}$; Ubc-Cre $\mathrm{ERT2/+}^{\mathrm{Rice}}$ and $\mathrm{Nrf2}^{-/-} ; \mathrm{Ubc}-\mathrm{Cre}^{\mathrm{ERT2/+}}$; Atg $7^{\text {flox/flox }}$ mice to generate $\mathrm{Nrf}^{-/-} ; \mathrm{Ubc}-\mathrm{Cre} \mathrm{ERT2/+}^{\mathrm{ERT}}$ p53 flox/flox mice and Nrf2 ${ }^{-/-}$; Ubc-Cre $e^{\text {ERT2/+ }} ; p^{2} 53^{\text {flox } / \text { flox }}$; Atg $7^{\text {flox/flox }}$ mice. After TAM administration, loss of $p 53$ in $N r f 2^{-/-} p 53^{\Delta / \Delta} A \operatorname{tg} 7^{\Delta / \Delta}$ intestine was confirmed by qRT-PCR, and we found that $N r f 2^{-/-} p 53^{\Delta / \Delta} A \operatorname{tg} 7^{\Delta / \Delta}$ mice did not survive longer than $N r f 2^{-/-} \operatorname{Atg} 7^{\Delta / \Delta}$ mice, suggest- ing that the intestinal damage in the $N r f 2^{-/-} A \operatorname{tg} 7^{\Delta / \Delta}$ mice was not caused by p53 (Supplemental Fig. S5G,H).

\section{Discussion}

Both autophagy and p53 can protect tissues from stress such as DNA damage, oxidative stress, and hypoxia (Mizushima and Komatsu 2011; Fischer 2017), and their overlapping functions have suggested that these two pathways interact. p53 up-regulates the expression of essential autophagy genes and autophagy function in vitro (Crighton et al. 2006; Feng et al. 2007; Zhang et al. 2009; Mah et al. 2012; Kenzelmann Broz et al. 2013). In turn, autophagy inhibits p53 in some tumors providing a negative feedback loop (Guo et al. 2013; Rosenfeldt et al. 2013; Strohecker et al. 2013; Yang et al. 2014). Whether autophagy can regulate p53 in normal tissues in vivo, however, was not clear. We found that Atg7 suppresses p53 activation in the liver and brain, without which hyperactivation of p53 is responsible for damage to these tissues. Thus, essential autophagy gene $\operatorname{Atg} 7$ is a tissue-specific negative regulator of $\mathrm{p} 53$ and contributes to a negative feedback loop to limit p53 activation in vivo (Fig. 5A). Remarkably, eliminating p53 also rescued the survival of Atg7-deficient mice during fasting, suggesting that Atg7 restricts p53 activation in response to exogenous as well as endogenous stress (Fig. 5). Even when p53 activation is forced by Nutlin-3, Atg7 prevents these tissues from p53-mediated damage (Fig. 5A,B). However, how p53 is activated remains unclear, which could either be a direct effect of loss of Atg7, or an indirect effect caused by cellular microenvironment change after $A \operatorname{tg} 7$ deletion. These findings are consistent with the observation that Nutlin-3 does not activate p53 in normal tissues unless under stress conditions caused by Atg 7 deficiency, but can efficiently activate p53 in different types of cancer cells without side effects on normal tissues (Vassilev et al. 2004; Drost et al. 2015; Yee-Lin et al. 2018; Forte et al. 2019). Therefore, autophagy may limit the effectiveness of MDM2 antagonists, and this should be tested in the cancer setting.

The NRF2 and autophagy pathways both contribute to antioxidant defense. NRF2 is activated by autophagy
A

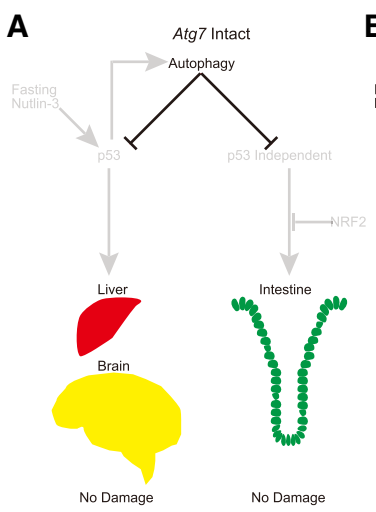

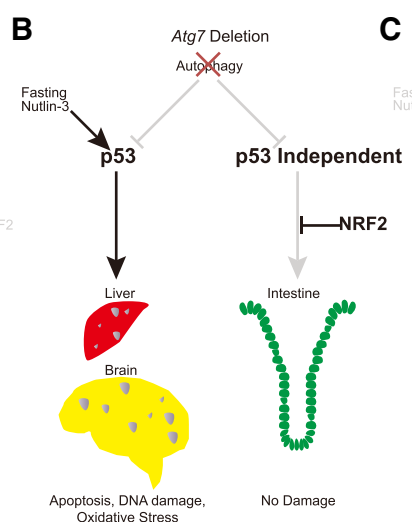

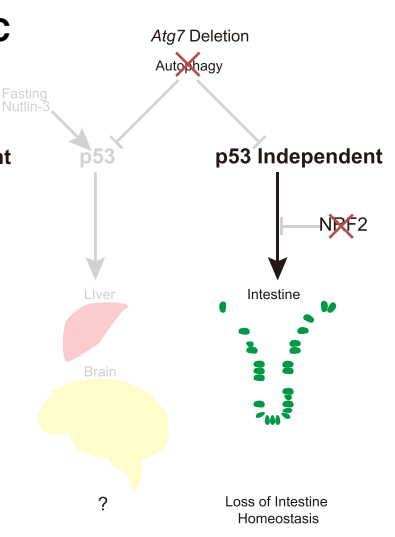

Figure 5. Mechanism by which autophagy interacts with the p53 and NRF2 stress response mechanisms to protect tissues in a tissue specific manner. See the text for details. 
deficiency in vitro and in tumors (Lau et al. 2010; Strohecker et al. 2013; Saito et al. 2016). The autophagy substrate p62, which accumulates when autophagy is blocked, interacts with KEAP1, thereby releasing and stabilizing NRF2 and promoting expression of its target genes (Komatsu et al. 2010; Lau et al. 2010; Ichimura et al. 2013; Levonen et al. 2014). We found that the protective function of NRF2 is essential for the survival of mice with loss of ATG7, as in stark contrast to $\operatorname{Atg} 7^{\Delta / \Delta}$ mice, $N r f 2^{-/-}$ $\operatorname{Atg} 7^{\Delta / \Delta}$ mice die rapidly, specifically from damage to the small intestine. Atg5 deficiency in intestine epithelia causes decreased numbers of intestinal stem cells, and these stem cells have a higher ROS level compared with wild-type mice, which can be rescued by treating mice with antioxidant $\mathrm{N}$-acetyl cysteine (Asano et al. 2017). Atg16L1 is also required to protect the intestinal epithelium from necroptosis induction in response to virusinduced intestinal bowel disease by maintaining mitochondrial homeostasis (Matsuzawa-Ishimoto et al. 2017). We report here that knockout of NRF2 is synthetically lethal with loss of $A t g 7$, which causes death within 1 wk before liver and brain damage can be observed, as NRF2 is specifically required to protect the survival of intestinal stem cells (Fig. 5C). The compensatory protective effect of NRF2 to loss of autophagy may be broad as recent cellbased screens identified NRF2 activation as a resistance mechanism selected for in cancer cells deleted for essential autophagy genes (Towers et al. 2019). In conclusion, autophagy limits p53 activation and damage in the liver and brain, while NRF2 limits intestinal stem cells damage due to loss of autophagy by a p53-independent mechanism. These findings demonstrate the functional interaction and tissue specificity of these stress regulated pathways (Fig. 5A-C).

ATG7 is an essential autophagy protein in the canonical autophagy pathway where it functions as an E1-like ubiquitin activating enzyme (Mizushima and Klionsky 2007). ATG7, however, also contributes to the other noncanonical LC3-dependent pathways LC3-associated phagocytosis (LAP) and LC3-associated endocytosis (LANDO). Macrophages use LAP to engulf and degrade particles and pathogens, which is immune-suppressive (Sanjuan et al. 2007; Florey et al. 2011; Martinez et al. 2011, 2015; Kim et al. 2013). LANDO is also immune suppressive and functions in microglia to remove the $\beta$-amyloid aggregates and protect the brain from neurodegeneration (Heckmann et al. 2019). Canonical autophagy, LAP, and LANDO all require autophagy machinery proteins including Beclin1, vacuolar protein sorting 34 (VPS34), ATG7, ATG5, and LC3, but activation of LAP or LANDO does not require some proteins in the autophagy initiation complexes such as RB1-inducible coiledcoil protein 1 (FIP200) (Martinez et al. 2011, 2015; Heckmann et al. 2019). Although LAP and LANDO have not been identified in hepatocytes, neurons, or intestinal stem cells as examined here, it would be interesting to test whether Fip200 deletion activates the p53 response in the liver and brain, or causes dependence on NRF2 in the intestine to distinguish roles of canonical and noncanonical autophagy pathways.

\section{Material and methods}

Mouse models

All animal care was carried out in compliance with Rutgers University Institutional Animal Care and Use Committee guidelines. $U b c-C r e^{E R T 2 /+}$ mice (The Jackson Laboratory) (Ruzankina et al. 2007) and Atg $7^{\text {flox/flox }}$ mice (provided by Dr. M. Komatsu, Tokyo Metropolitan Institute of Medical Science) (Komatsu et al. 2005) were cross-bred to generate the Ubc-Cre $e^{E R T 2 /+}$; Atg flox/flox mice as described previously (Karsli-Uzunbas et al. 2014). To generate $U b c-C r e^{E R T 2 /+} ; A \operatorname{tg} 7^{\text {flox/flox }} ; p 53^{\text {flox/flox }}$ mice, p53 flox/flox mice (The Jackson Laboratory) (Marino et al. 2000) were cross-bred with our previously created $\mathrm{Ubc}-\mathrm{Cre} \mathrm{ERT2/+}^{\mathrm{ERT}}$; Atg fflox/flox mice. To generate Nrf2 $2^{-/-}$; Ubc-Cre $e^{E R T 2 /+}$ mice and

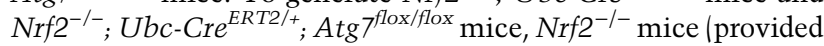
by YW Kan, University of California at San Francisco) (Chan et al. 1996) were cross-bred with $\mathrm{Ubc}-\mathrm{Cr} e^{E R T 2 /+}$ mice and our previously generated $\mathrm{Ubc}-\mathrm{Cre} \mathrm{ERT2/+}^{\mathrm{E}}$ Atg $7^{\text {flox/flox }}$ mice.

\section{TAM administration}

For acute deletion of $A \operatorname{tg} 7$ and/or p53, detailed rationale and TAM preparation is described as published previously (Karsli-Uzunbas et al. 2014). For TAM delivery to the adult mice, $200 \mu \mathrm{L}$ of the suspended solution per $20 \mathrm{~g}$ of body weight was injected intraperitoneally (IP) into 8- to 10 -wk-old $U b c-C r e^{E R T 2 /+} ; A t g 7^{\text {flox/flox }}$ mice and $U b c-C r e^{E R T 2 /+} ; A \operatorname{tg} 7^{\text {flox/flox }} ; p 53^{\text {flox/flox }}$ mice once per day for five consecutive days to delete the floxed gene systematically. Additionally, the same dosages of TAM were given to $U b c$ $C r e^{E R T 2 /+}$ mice and $\mathrm{Ubc}-\mathrm{Cr} e^{E R T 2 /+}$; $p 53^{\text {flox/flox }}$ mice, and these mice were examined as control groups.

Statistical methods

Survival curves were estimated using the Kaplan-Meier method. Comparisons of survival curves were made using the log-rank test and Gehan-Breslow-Wilcoxon test (Cox and Oakes 1984).

\section{Fasting}

Fasting was conducted as described previously (Karsli-Uzunbas et al. 2014).

\section{Histology}

Mouse tissues were collected and fixed in $10 \%$ formalin solution (Formaldehyde Fresh, Fisher Scientific SF94-4). Tissues were fixed overnight and then transferred to $70 \%$ ethanol for paraffin-embedded sections or $15 \%$ sucrose following by $30 \%$ sucrose for frozen sections. For Alcian blue staining, paraffin sections were processed with the Alcian blue stain kit (Abcam) following the manufacturer's protocol. For Bodipy C11 (Thermo Scientific D3861) stain, $5 \mu \mathrm{M}$ Bodipy C11 dye were used to stain the frozen sections of intestine for $30 \mathrm{~min}$ and counterstained with DAPI. For IHC, paraffin sections were stained with antibodies against p53 (1:400; Novus Biologicals NB200-103), active caspase-3 (1:300; Cell Signaling 9661), $\gamma$-H2AX (1:480; Cell Signaling 9718), MDA (1:200; Cosmo Bio USA NOF-N213530-EX), OLFM4 (1:2000; Cell Signaling 39141), Lysozyme (1:2000; Agilent A0099). For quantification of IHC on p53, active caspase-3, and $\gamma-\mathrm{H} 2 \mathrm{AX}$, the liver and brain tissues were analyzed by quantifying at least 10 images at $60 \times$ magnification using ImageJ. A minimum of 100 cells in the liver and brain was scored for each image. 
Nutlin-3a administration

TAM were injected via IP into 8- to 10 -wk-old $\mathrm{Ubc}$-Cre $e^{E R T 2 /+}$ Atg $7^{\text {flox/flox }}$ mice and $U b c-C r e^{E R T 2 /+} ; A \operatorname{tg} 7^{\text {flox } / \text { flox }} ; p 53^{\text {flox/flox }}$ mice once per day for five consecutive days. Additionally, same dosages of TAM were given to $\mathrm{Ubc}-\mathrm{Cr} e^{E R T 2 /+}$ mice and $\mathrm{Ubc}$ $C r e^{E R T 2 /+}$; $p 53^{\text {flox/flox }}$ mice. After $2 \mathrm{wk}, 200 \mathrm{mg} / \mathrm{kg}$ Nutlin-3 (Cayman Chemicals) resolved in $50 \%$ DMSO was delivered to the mice by oral gavage once per day for seven consecutive days. Mice were sacrificed $1 \mathrm{~d}$ after the last administration of Nutlin3 and tissues were collected for histology and snap-frozen for Western blot and real-time PCR.

\section{Real-time PCR}

Total RNA were isolated from tissue by Trizol (Invitrogen). cDNA were then reverse-transcribed from the total RNA by MultiScribe RT kit (Thermo Fisher). Real-time PCR were performed on Applied Biosystems StepOne Plus machine. Atg7 and p53 were performed using SYBR Green for deletion detection (Atg7: forward 5'-ACTTGACCGGTCTTACCCTG-3'; reverse 5'-TAC TCCTGAGCTGTGGTTGC-3' p53: forward: 5'-CGACTACAGT TAGGGGGCAC-3'; reverse: 5'-GGAGGAAGTAGTTTCCATA AGCCT-3'; Actin: forward 5'-GAACCCTAAGGCCAACCGT GAAAAGATGAC-3'; reverse 5' GCAGGATGGCGTGAGGGA GAGCA- $3^{\prime}$ ). Besides that, all of the other genes were detected using predesigned commercial TaqMan primers for each gene accordingly |Cdkn1a: Mm00432448-m1; Bax: Mm00432050; Bbc3: Mm00519268; Actin: Mm00607939-s1; Uvrag: Mm0072 4370-m1; Ulk1: Mm0437238-m1; Ulk2: Mm03048846-m1; Vmp1: Mm00774656-m1; Atg2b: Mm006 20760-m1; Atg4a: Mm04214755-s1; Atg4c: Mm00558175-m1; and Atg10: Mm00470550-m1). Results were calculated using the $\Delta \Delta \mathrm{C}_{\mathrm{T}}$ method and then normalized to actin.

\section{Western blot}

Different tissues were ground in a Cryomill machine (Retsch) and then total protein extracts were isolated by Tris lysis buffer $(1$ $\mathrm{mol} / \mathrm{L}$ Tris $\mathrm{HCl}, 1 \mathrm{~mol} / \mathrm{L} \mathrm{NaCl}, 0.1 \mathrm{~mol} / \mathrm{L}$ EDTA, 10\% NP40). Separated proteins were probed with antibodies against ATG7 (1:2000; Sigma A2856), LC3 (1:1500; Novus Biologicals NB6001384), p62 (1:2000; American Research Products 03-GP62-C), GAPDH (1:1000; Santa Cruz Biotechnology sc-365062), and $\beta$-actin (1:5000; Sigma A1978).

\section{Acknowledgments}

This work was supported by the National Institutes of Health grants R01 CA130893, CA188096, and CA163591 (to E.W.). Services, results, and/or products in support of the research project were generated by the Rutgers Cancer Institute of New Jersey Biospecimen Repository and Histopathology Service Shared Resource, supported in part with funding from National Cancer Institute-Cancer Center Support Grant (NCI-CCSG) P30CA072720-5919; and the Biometrics Shared Resource, supported in part with funding from NCI-CCSG P30CA0727205918.

Author contributions: Y.Y. performed the majority of the experimental work and wrote the manuscript. G.K.-U. performed some of the survival experiments and the fasting experiment and assisted with IHC tissue preparation from wild-type, $A \operatorname{tg} 7^{\Delta / \Delta}$, $p 53^{\Delta / \Delta}$, and $A \operatorname{tg} 7^{\Delta / \Delta} p 53^{\Delta / \Delta}$ mice. L.P.-P. and A.S. assisted with the Western blot and quantification of IHC. Z.S.H. assisted with the mouse husbandry. Y.Z. and W.H. assisted with the qRT-PCR.
D.M. assisted with the statistics. E.W. was the leading principal investigator who conceived and supervised on the project and edited the paper.

\section{References}

Asano J, Sato T, Ichinose S, Kajita M, Onai N, Shimizu S, Ohteki T. 2017. Intrinsic autophagy is required for the maintenance of intestinal stem cells and for irradiation-induced intestinal regeneration. Cell Rep 20: 1050-1060. doi:10.1016/j.celrep.2017 .07 .019

Bode AM, Dong Z. 2004. Post-translational modification of p53 in tumorigenesis. Nat Rev Cancer 4: 793-805. doi:10.1038/ nrc 1455

Cadwell K, Liu JY, Brown SL, Miyoshi H, Loh J, Lennerz JK, Kishi C, Kc W, Carrero JA, Hunt S, et al. 2008. A key role for autophagy and the autophagy gene $\operatorname{Atg} 1611$ in mouse and human intestinal Paneth cells. Nature 456: 259-263. doi:10.1038/ nature 07416

Chan K, Lu R, Chang JC, Kan YW. 1996. NRF2, a member of the NFE2 family of transcription factors, is not essential for murine erythropoiesis, growth, and development. Proc Natl Acad Sci 93: 13943-13948. doi:10.1073/pnas.93.24 .13943

Cox DR, Oakes D. 1984. Analysis of survival data. Chapman and Hall, London; New York.

Craig AL, Burch L, Vojtesek B, Mikutowska J, Thompson A, Hupp TR. 1999. Novel phosphorylation sites of human tumour suppressor protein p53 at Ser20 and Thr18 that disrupt the binding of $\mathrm{mdm} 2$ (mouse double minute 2) protein are modified in human cancers. Biochem I 342: 133-141. doi:10.1042/ bj3420133

Crighton D, Wilkinson S, O'Prey J, Syed N, Smith P, Harrison PR, Gasco M, Garrone O, Crook T, Ryan KM. 2006. DRAM, a p53induced modulator of autophagy, is critical for apoptosis. Cell 126: 121-134. doi:10.1016/j.cell.2006.05.034

Donehower LA, Harvey M, Vogel H, McArthur MJ, Montgomery CA Jr, Park SH, Thompson T, Ford RJ, Bradley A. 1995. Effects of genetic background on tumorigenesis in p53-deficient mice. Mol Carcinog 14: 16-22. doi:10.1002/mc.2940140105

Dotto GP. 2009. Crosstalk of Notch with p53 and p63 in cancer growth control. Nat Rev Cancer 9: 587-595. doi:10.1038/ nrc2675

Drost J, van Jaarsveld RH, Ponsioen B, Zimberlin C, van Boxtel R, Buijs A, Sachs N, Overmeer RM, Offerhaus GJ, Begthel H, et al. 2015. Sequential cancer mutations in cultured human intestinal stem cells. Nature 521: 43-47. doi:10.1038/ nature 14415

Feng Z, Hu W, de Stanchina E, Teresky AK, Jin S, Lowe S, Levine AJ. 2007. The regulation of AMPK $\beta 1$, TSC2, and PTEN expression by p53: stress, cell and tissue specificity, and the role of these gene products in modulating the IGF-1-AKT-mTOR pathways. Cancer Res 67: 3043-3053. doi:10.1158/00085472.CAN-06-4149

Fischer M. 2017. Census and evaluation of p53 target genes. Oncogene 36: 3943-3956. doi:10.1038/onc.2016.502

Florey O, Kim SE, Sandoval CP, Haynes CM, Overholtzer M. 2011. Autophagy machinery mediates macroendocytic processing and entotic cell death by targeting single membranes. Nat Cell Biol 13: 1335-1343. doi:10.1038/ncb2363

Forte IM, Indovina P, Iannuzzi CA, Cirillo D, Di Marzo D, Barone D, Capone F, Pentimalli F, Giordano A. 2019. Targeted therapy based on p53 reactivation reduces both glioblastoma cell 
growth and resistance to temozolomide. Int I Oncol 54: 21892199. doi:10.3892/ijo.2019.4788

Guo JY, Karsli-Uzunbas G, Mathew R, Aisner SC, Kamphorst JJ, Strohecker AM, Chen G, Price S, Lu W, Teng X, et al. 2013. Autophagy suppresses progression of K-ras-induced lung tumors to oncocytomas and maintains lipid homeostasis. Genes Dev 27: 1447-1461. doi:10.1101/gad.219642.113

Guo JY, Teng X, Laddha SV, Ma S, Van Nostrand SC, Yang Y, Khor S, Chan CS, Rabinowitz JD, White E. 2016. Autophagy provides metabolic substrates to maintain energy charge and nucleotide pools in Ras-driven lung cancer cells. Genes Dev 30: 1704-1717. doi:10.1101/gad.283416.116

Heckmann BL, Teubner BJW, Tummers B, Boada-Romero E, Harris L, Yang M, Guy CS, Zakharenko SS, Green DR. 2019. LC3associated endocytosis facilitates $\beta$-amyloid clearance and mitigates neurodegeneration in murine Alzheimer's disease. Cell 178: 536-551 e514. doi:10.1016/j.cell.2019.05.056

Honda R, Tanaka H, Yasuda H. 1997. Oncoprotein MDM2 is a ubiquitin ligase E3 for tumor suppressor p53. FEBS Lett 420: 25-27. doi:10.1016/S0014-5793(97)01480-4

Huo Y, Cai H, Teplova I, Bowman-Colin C, Chen G, Price S, Barnard N, Ganesan S, Karantza V, White E, et al. 2013. Autophagy opposes p53-mediated tumor barrier to facilitate tumorigenesis in a model of PALB2-associated hereditary breast cancer. Cancer Discov 3: 894-907. doi:10.1158/21598290.CD-13-0011

Ichimura Y, Waguri S, Sou YS, Kageyama S, Hasegawa J, Ishimura R, Saito T, Yang Y, Kouno T, Fukutomi T, et al. 2013. Phosphorylation of p62 activates the Keap1-Nrf2 pathway during selective autophagy. Mol Cell 51: 618-631. doi:10.1016/j .molcel.2013.08.003

Karsli-Uzunbas G, Guo JY, Price S, Teng X, Laddha SV, Khor S, Kalaany NY, Jacks T, Chan CS, Rabinowitz JD, et al. 2014. Autophagy is required for glucose homeostasis and lung tumor maintenance. Cancer Discov 4: 914-927. doi:10.1158/ 2159-8290.CD-14-0363

Kaur J, Debnath J. 2015. Autophagy at the crossroads of catabolism and anabolism. Nat Rev Mol Cell Biol 16: 461-472. doi:10.1038/nrm4024

Kensler TW, Wakabayashi N, Biswal S. 2007. Cell survival responses to environmental stresses via the Keap1-Nrf2-ARE pathway. Annu Rev Pharmacol Toxicol 47: 89-116. doi:10 .1146/annurev.pharmtox.46.120604.141046

Kenzelmann Broz D, Spano Mello S, Bieging KT, Jiang D, Dusek RL, Brady CA, Sidow A, Attardi LD. 2013. Global genomic profiling reveals an extensive p53-regulated autophagy program contributing to key p53 responses. Genes Dev 27: 1016-1031. doi:10.1101/gad.212282.112

Khoury K, Domling A. 2012. P53 mdm2 inhibitors. Curr Pharm Des 18: 4668-4678. doi:10.2174/138161212802651580

Kim JY, Zhao H, Martinez J, Doggett TA, Kolesnikov AV, Tang PH, Ablonczy Z, Chan CC, Zhou Z, Green DR, et al. 2013. Noncanonical autophagy promotes the visual cycle. Cell 154: 365-376. doi:10.1016/j.cell.2013.06.012

Komatsu M, Waguri S, Ueno T, Iwata J, Murata S, Tanida I, Ezaki J, Mizushima N, Ohsumi Y, Uchiyama Y, et al. 2005. Impairment of starvation-induced and constitutive autophagy in Atg7-deficient mice. I Cell Biol 169: 425-434. doi:10.1083/ jcb.200412022

Komatsu M, Kurokawa H, Waguri S, Taguchi K, Kobayashi A, Ichimura Y, Sou YS, Ueno I, Sakamoto A, Tong KI, et al. 2010. The selective autophagy substrate p62 activates the stress responsive transcription factor Nrf2 through inactivation of Keap1. Nat Cell Biol 12: 213-223. doi:10.1038/ncb2021
Kruiswijk F, Labuschagne CF, Vousden KH. 2015. p53 in survival, death and metabolic health: a lifeguard with a licence to kill. Nat Rev Mol Cell Biol 16: 393-405. doi:10.1038/nrm4007

Kubbutat MH, Jones SN, Vousden KH. 1997. Regulation of p53 stability by Mdm2. Nature 387: 299-303. doi:10.1038/ $387299 \mathrm{a} 0$

Kuma A, Hatano M, Matsui M, Yamamoto A, Nakaya H, Yoshimori T, Ohsumi Y, Tokuhisa T, Mizushima N. 2004. The role of autophagy during the early neonatal starvation period. $\mathrm{Na}$ ture 432: 1032-1036. doi:10.1038/nature03029

Lau A, Wang XJ, Zhao F, Villeneuve NF, Wu T, Jiang T, Sun Z, White E, Zhang DD. 2010. A noncanonical mechanism of Nrf2 activation by autophagy deficiency: direct interaction between Keapl and p62. Mol Cell Biol 30: 3275-3285. doi:10 .1128/MCB.00248-10

Levonen AL, Hill BG, Kansanen E, Zhang J, Darley-Usmar VM. 2014. Redox regulation of antioxidants, autophagy, and the response to stress: implications for electrophile therapeutics. Free Radic Biol Med 71: 196-207. doi:10.1016/j .freeradbiomed.2014.03.025

Mah LY, O'Prey J, Baudot AD, Hoekstra A, Ryan KM. 2012. DRAM-1 encodes multiple isoforms that regulate autophagy. Autophagy 8: 18-28. doi:10.4161/auto.8.1.18077

Mancias JD, Wang X, Gygi SP, Harper JW, Kimmelman AC. 2014. Quantitative proteomics identifies NCOA4 as the cargo receptor mediating ferritinophagy. Nature 509: 105-109. doi:10.1038/nature13148

Manjithaya R, Nazarko TY, Farre JC, Subramani S. 2010. Molecular mechanism and physiological role of pexophagy. FEBS Lett 584: 1367-1373. doi:10.1016/j.febslet.2010.01.019

Marine JC, Lozano G. 2010. Mdm2-mediated ubiquitylation: p53 and beyond. Cell Death Differ 17: 93-102. doi:10.1038/cdd .2009 .68

Marino S, Vooijs M, van Der Gulden H, Jonkers J, Berns A. 2000. Induction of medulloblastomas in p53-null mutant mice by somatic inactivation of $\mathrm{Rb}$ in the external granular layer cells of the cerebellum. Genes Dev 14: 994-1004.

Martinez J, Almendinger J, Oberst A, Ness R, Dillon CP, Fitzgerald P, Hengartner MO, Green DR. 2011. Microtubule-associated protein 1 light chain $3 \alpha$ (LC3)-associated phagocytosis is required for the efficient clearance of dead cells. Proc Natl Acad Sci 108: 17396-17401. doi:10.1073/pnas.1113421108

Martinez J, Malireddi RK, Lu Q, Cunha LD, Pelletier S, Gingras S, Orchard R, Guan JL, Tan H, Peng J, et al. 2015. Molecular characterization of LC3-associated phagocytosis reveals distinct roles for Rubicon, NOX2 and autophagy proteins. Nat Cell Biol 17: 893-906. doi:10.1038/ncb3192

Mathew R, Karp CM, Beaudoin B, Vuong N, Chen G, Chen HY, Bray K, Reddy A, Bhanot G, Gelinas C, et al. 2009. Autophagy suppresses tumorigenesis through elimination of p62. Cell 137: 1062-1075. doi:10.1016/j.cell.2009.03.048

Mathew R, Khor S, Hackett SR, Rabinowitz JD, Perlman DH, White E. 2014. Functional role of autophagy-mediated proteome remodeling in cell survival signaling and innate immunity. Mol Cell 55: 916-930. doi:10.1016/j.molcel.2014.07.019

Matsumine H, Saito M, Shimoda-Matsubayashi S, Tanaka H, Ishikawa A, Nakagawa-Hattori Y, Yokochi M, Kobayashi T, Igarashi S, Takano H, et al. 1997. Localization of a gene for an autosomal recessive form of juvenile Parkinsonism to chromosome 6q25.2-27. Am J Hum Genet 60: 588-596.

Matsuzawa-Ishimoto Y, Shono Y, Gomez LE, Hubbard-Lucey VM, Cammer M, Neil J, Dewan MZ, Lieberman SR, Lazrak A, Marinis JM, et al. 2017. Autophagy protein ATG16L1 prevents necroptosis in the intestinal epithelium. I Exp Med 214: 3687-3705. doi: $10.1084 /$ jem. 20170558 
Mizushima N. 2010. The role of the Atg1/ULK1 complex in autophagy regulation. Curr Opin Cell Biol 22: 132-139. doi:10.1016/j.ceb.2009.12.004

Mizushima N, Klionsky DJ. 2007. Protein turnover via autophagy: implications for metabolism. Annu Rev Nutr 27: 19-40. doi:10.1146/annurev.nutr.27.061406.093749

Mizushima N, Komatsu M. 2011. Autophagy: renovation of cells and tissues. Cell 147: 728-741. doi:10.1016/j.cell.2011.10.026

Mizushima N, Yamamoto A, Matsui M, Yoshimori T, Ohsumi Y. 2004. In vivo analysis of autophagy in response to nutrient starvation using transgenic mice expressing a fluorescent autophagosome marker. Mol Biol Cell 15: 1101-1111. doi:10 .1091/mbc.e03-09-0704

Montes de Oca Luna R, Wagner DS, Lozano G. 1995. Rescue of early embryonic lethality in mdm2-deficient mice by deletion of p53. Nature 378: 203-206. doi:10.1038/378203a0

Pohl C, Dikic I. 2019. Cellular quality control by the ubiquitinproteasome system and autophagy. Science 366: 818-822. doi:10.1126/science.aax3769

Poillet-Perez L, White E. 2019. Role of tumor and host autophagy in cancer metabolism. Genes Dev 33: 610-619. doi:10.1101/ gad.325514.119

Rabinowitz JD, White E. 2010. Autophagy and metabolism. Science 330: 1344-1348. doi:10.1126/science.1193497

Rosenfeldt MT, O’Prey J, Morton JP, Nixon C, MacKay G, Mrowinska A, Au A, Rai TS, Zheng L, Ridgway R, et al. 2013. p53 status determines the role of autophagy in pancreatic tumour development. Nature 504: 296-300. doi:10.1038/ nature 12865

Ruzankina Y, Pinzon-Guzman C, Asare A, Ong T, Pontano L, Cotsarelis G, Zediak VP, Velez M, Bhandoola A, Brown EJ. 2007. Deletion of the developmentally essential gene ATR in adult mice leads to age-related phenotypes and stem cell loss. Cell Stem Cell 1: 113-126. doi:10.1016/j.stem.2007.03 .002

Saito T, Ichimura Y, Taguchi K, Suzuki T, Mizushima T, Takagi K, Hirose Y, Nagahashi M, Iso T, Fukutomi T, et al. 2016. p62/ Sqstm1 promotes malignancy of HCV-positive hepatocellular carcinoma through Nrf2-dependent metabolic reprogramming. Nat Commun 7: 12030. doi:10.1038/ncomms 12030

Sanjuan MA, Dillon CP, Tait SW, Moshiach S, Dorsey F, Connell S, Komatsu M, Tanaka K, Cleveland JL, Withoff S, et al. 2007. Toll-like receptor signalling in macrophages links the autoph- agy pathway to phagocytosis. Nature 450: 1253-1257. doi:10 .1038 /nature06421

Strohecker AM, Guo JY, Karsli-Uzunbas G, Price SM, Chen GJ, Mathew R, McMahon M, White E. 2013. Autophagy sustains mitochondrial glutamine metabolism and growth of BrafV600E-driven lung tumors. Cancer Discov 3: 1272-1285. doi:10.1158/2159-8290.CD-13-0397

Toledo F, Wahl GM. 2006. Regulating the p53 pathway: in vitro hypotheses, in vivo veritas. Nat Rev Cancer 6: 909-923. doi: $10.1038 / \mathrm{nrc} 2012$

Towers CG, Fitzwalter BE, Regan D, Goodspeed A, Morgan MJ, Liu CW, Gustafson DL, Thorburn A. 2019. Cancer cells upregulate NRF2 signaling to adapt to autophagy inhibition. DeV Cell 50: 690-703 e696. doi:10.1016/j.devcel.2019.07.010

Vassilev LT, Vu BT, Graves B, Carvajal D, Podlaski F, Filipovic Z, Kong N, Kammlott U, Lukacs C, Klein C, et al. 2004. In vivo activation of the p53 pathway by small-molecule antagonists of MDM2. Science 303: 844-848. doi:10.1126/science .1092472

Yang A, Kimmelman AC. 2014. Inhibition of autophagy attenuates pancreatic cancer growth independent of TP53/TRP53 status. Autophagy 10: 1683-1684. doi:10.4161/auto.29961

Yang S, Wang X, Contino G, Liesa M, Sahin E, Ying H, Bause A, Li Y, Stommel JM, Dell'antonio G, et al. 2011. Pancreatic cancers require autophagy for tumor growth. Genes Dev 25: 717-729. doi:10.1101/gad.2016111

Yang A, Rajeshkumar NV, Wang X, Yabuuchi S, Alexander BM, Chu GC, Von Hoff DD, Maitra A, Kimmelman AC. 2014. Autophagy is critical for pancreatic tumor growth and progression in tumors with p53 alterations. Cancer Discov 4: 905913. doi:10.1158/2159-8290.CD-14-0362

Yee KS, Wilkinson S, James J, Ryan KM, Vousden KH. 2009. PUMA- and Bax-induced autophagy contributes to apoptosis. Cell Death Differ 16: 1135-1145. doi:10.1038/cdd.2009.28

Yee-Lin V, Pooi-Fong W, Soo-Beng AK. 2018. Nutlin-3, A p53-Mdm2 antagonist for nasopharyngeal carcinoma treatment. Mini Rev Med Chem 18: 173-183. doi:10.2174/ 1389557517666170717125821

Zhang XD, Wang Y, Wang Y, Zhang X, Han R, Wu JC, Liang ZQ, Gu ZL, Han F, Fukunaga K, et al. 2009. p53 mediates mitochondria dysfunction-triggered autophagy activation and cell death in rat striatum. Autophagy 5: 339-350. doi:10 $.4161 /$ auto.5.3.8174 


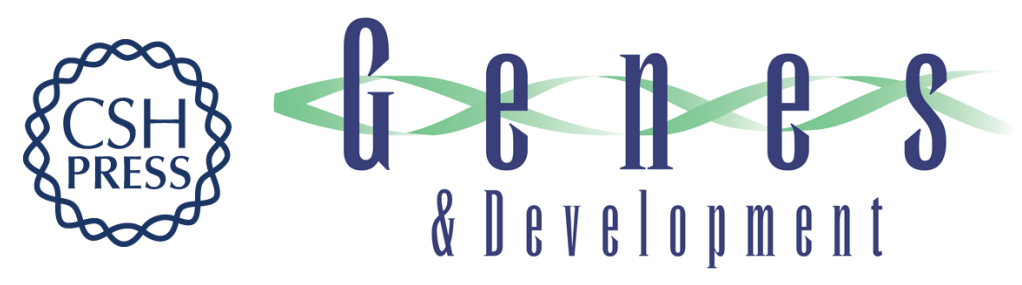

\section{Autophagy promotes mammalian survival by suppressing oxidative stress and p53}

Yang Yang, Gizem Karsli-Uzunbas, Laura Poillet-Perez, et al.

Genes Dev. 2020, 34: originally published online March 19, 2020

Access the most recent version at doi:10.1101/gad.335570.119

\section{Supplemental http://genesdev.cshlp.org/content/suppl/2020/03/18/gad.335570.119.DC1 Material}

References This article cites 65 articles, 21 of which can be accessed free at: http://genesdev.cshlp.org/content/34/9-10/688.full.html\#ref-list-1

Creative This article is distributed exclusively by Cold Spring Harbor Laboratory Press for the first Commons six months after the full-issue publication date (see

License http://genesdev.cshlp.org/site/misc/terms.xhtml). After six months, it is available under a Creative Commons License (Attribution-NonCommercial 4.0 International), as described at http://creativecommons.org/licenses/by-nc/4.0/.

Email Alerting Receive free email alerts when new articles cite this article - sign up in the box at the top Service right corner of the article or click here.

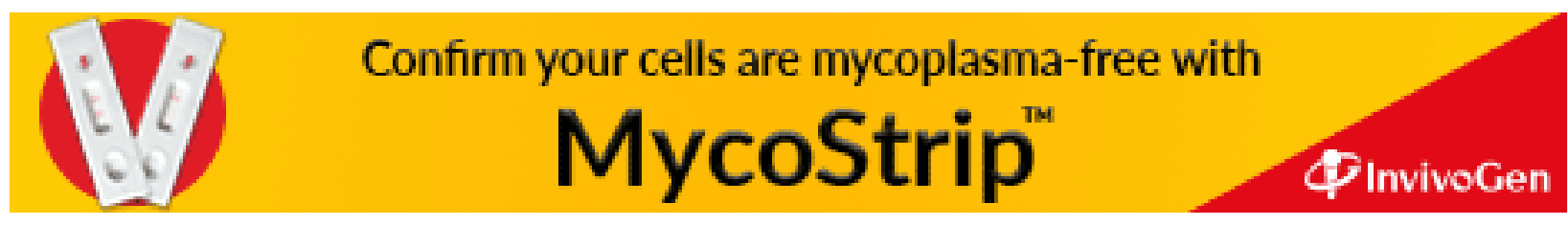

